\title{
Altitude and Vegetation Affect Soil Organic Carbon, Basal Respiration and Microbial Biomass in Apennine Forest Soils
}

\author{
Luisa Massaccesi ${ }^{1,2}$, Mauro De Feudis ${ }^{3, * \mathbb{C}}$, Angelo Leccese ${ }^{2}$ and Alberto Agnelli ${ }^{2,4}$ (i) \\ 1 Istituto Zooprofilattico Sperimentale dell’Umbria e delle Marche ‘Togo Rosati', Via G. Salvemini, 1, \\ 06126 Perugia, Italy; luisa.massaccesi@gmail.com \\ 2 Department of Agricultural, Food and Environmental Sciences, University of Perugia, Borgo XX giugno, 74, \\ 06121 Perugia, Italy; angelo.leccese@unipg.it (A.L.); alberto.agnelli@unipg.it (A.A.) \\ 3 Department of Agricultural and Food Sciences, Alma Mater Studiorum-University of Bologna, Via Fanin, 40, \\ 40127 Bologna, Italy \\ 4 Research Institute on Terrestrial Ecosystem (IRET-CNR), Via Madonna del Piano, 10, \\ 50019 Sesto Fiorentino (FI), Italy \\ * Correspondence: mauro.defeudis2@unibo.it
}

Received: 15 May 2020; Accepted: 25 June 2020; Published: 26 June 2020

\begin{abstract}
Both altitude and vegetation are known to affect the amount and quality of soil organic matter (SOM) and the size and activity of soil microbial biomass. However, when altitude and vegetation changes are combined, it is still unclear which one has a greater effect on soil chemical and biochemical properties. With the aim of clarifying this, we tested the effect of altitude (and hence temperature) and vegetation (broadleaf vs pine forests) on soil organic carbon (SOC) and soil microbial biomass and its activity. Soil sampling was carried out in two adjacent toposequences ranging from 500 to $1000 \mathrm{~m}$ a.s.l. on a calcareous massif in central Italy: one covered only by Pinus nigra J.F. Arnold forests, while the other covered by Quercus pubescens Willd., Ostrya carpinifolia Scop. and Fagus sylvatica L. forests, at 500, 700 and $1000 \mathrm{~m}$ a.s.l., respectively. The content of SOC and water-extractable organic carbon (WEOC) increased with altitude for the pine forests, while for the broadleaf forests no trend along the slope occurred, and the highest SOC and WEOC contents were observed in the soil at $700 \mathrm{~m}$ under the Ostrya carpinifolia forest. With regard to the soil microbial community, although the size of the soil microbial biomass (Cmic) generally followed the SOC contents along the slope, both broadleaf and pine forest soils showed similar diminishing trends with altitude of soil respiration $(\Sigma \mathrm{CO} 2-\mathrm{C})$, and $\Sigma \mathrm{CO} 2-\mathrm{C}: W E O C$ and $\Sigma \mathrm{CO} 2-\mathrm{C}: \mathrm{Cmic}$ ratios. The results pointed out that, although under the pine forests' altitude was effective in affecting WEOC and SOC contents, in the soils along the broadleaf forest toposequence this effect was absent, indicating a greater impact of vegetation than temperature on SOC amount and pool distribution. Conversely, the similar trend with altitude of the microbial activity indexes would indicate temperature to be crucial for the activity of the soil microbial community.
\end{abstract}

Keywords: forest soil; soil organic carbon; water extractable organic carbon; soil microbial activity; toposequence

\section{Introduction}

Soil comprises the largest pool of terrestrial carbon (C) and, through the soil organic matter (SOM) cycling, it represents either an important sink of $\mathrm{C}$ or a possible source of $\mathrm{CO}_{2}$ [1]. SOM includes a wide range of compounds at different stages of decomposition derived from litter, root turnover, and microorganisms, and its dynamics are controlled by the quality of the substrate, the activity of 
the organisms, and the environmental conditions [2]. Among the environmental factors, climate (temperature and precipitation), is considered the most important factor regulating the soil organic $\mathrm{C}$ (SOC) turnover [3] by directly affecting the microbial activity [3-5] and by constantly influencing the soil weathering processes [6] and nutrient cycles [7-9]. Since air and soil temperature are controlled by physiographic factors, such as latitude, altitude, and exposure [10-12], altitude has been often used as a proxy for temperature change to assess the effect of temperature on SOC content and dynamics. Among others, Gutiérrez-Girón et al. [13] studied the influence of temperature on SOC and microbial activity of shrubland and grassland soils in Central Spain along an altitudinal gradient ranging from 2100 to $2800 \mathrm{~m}$ a.s.l. They found a high temperature susceptibility of SOM decomposition in the areas at higher altitude. Chang et al. [14], investigating vertical distribution of SOC and soil total N in soils of three Tibetan montane forests along a wide altitudinal and thermal gradient (from 1700 to $4300 \mathrm{~m}$ a.s.l. and from 15.5 to $1.7^{\circ} \mathrm{C}$, respectively), reported that the shift of plant species with altitude had a greater role than temperature in affecting SOC distribution throughout the soil profile. Tsozué et al. [15] attributed the greater SOC content of the Andosols in the upper part of an altitudinal gradient (1400-2740 m a.s.l.) on the Bambouto Mountains (Cameroon), other than to the soil properties, to the lower temperature which limited the decomposition of the plant litter. However, the effect of temperature changes on SOC dynamics and content in forest ecosystems is still poorly known because of the scarce information on how, and how fast, changes affect the balance among input, degradation and stabilization mechanisms [16-20]. Other than climate, vegetation is also considered to affect the SOC cycle through the quality and quantity of both litters and root exudates that, in turn, can influence the soil fauna and microbial processes [11]. For example, Quideau et al. [21] in the San Dimas Experimental Forest (U.S.A.) found a better efficiency in incorporating the litter and its degradation products into the A horizon under oak than under pine forest, suggesting a greater activity of the soil organisms under oak forest. Vegetation can also affect SOC quality through the relative abundance of labile and recalcitrant $C$ compounds returned to soil as a function of the specific composition of the living tissues [22]. Although clear differences in litter composition occur between plant species (e.g., broadleaves vs pine), the effect of vegetation type on SOC quality and abundance, specifically in relation to temperature, has been scarcely investigated e.g., [23-27].

With the aim to contribute to the knowledge of the role of vegetation and altitude, and hence temperature, on the organic $\mathrm{C}$ accumulation in forest soils, we considered two adjacent toposequences ranging from 500 to $1000 \mathrm{~m}$ a.s.l. along the west flanks of a calcareous massif in Central Italy: one covered only by pine (Pinus nigra J.F. Arnold) reforestations, the other covered by autochthonous forests (mixed wood dominated by Quercus pubescens Willd. at $500 \mathrm{~m}$ a.s.l.; Ostrya carpinifolia Scop. at $700 \mathrm{~m}$ a.s.l.; Fagus sylvatica L. at 1000 a.s.l.). The objective of this research was to assess the combined effect of the altitude-dependent temperature and the vegetations (broadleaf vs pine forests) on (1) SOC pools and (2) soil microbial biomass and its activity. We hypothesized that: (i) SOC contents increase with altitude; (ii) SOC stocks are greater under pine than broadleaf forests; (iii) the activity of the soil microbial community declines with altitude.

\section{Materials and Methods}

\subsection{Study Sites}

We selected three sites at about 500, 700 and $1000 \mathrm{~m}$ a.s.l. along the northwest-facing slope of Mount Cucco (Figure 1), a calcareous massif on the Apennines chain (Umbria region, Central Italy). At each site, two adjacent forests were chosen, one comprised of a pine (Pinus nigra J.F. Arnold) reforestation established during the late 1970s, and the other by authoctonous broadleaf species [(mixed wood dominated by downy oak (Quercus pubescens Willd.) at $500 \mathrm{~m}$ a.s.l., European hop-hornbeam (Ostrya carpinifolia Scop.) at $700 \mathrm{~m}$ a.s.l., and beech (Fagus sylvatica L.) at 1000 a.s.l.]. 


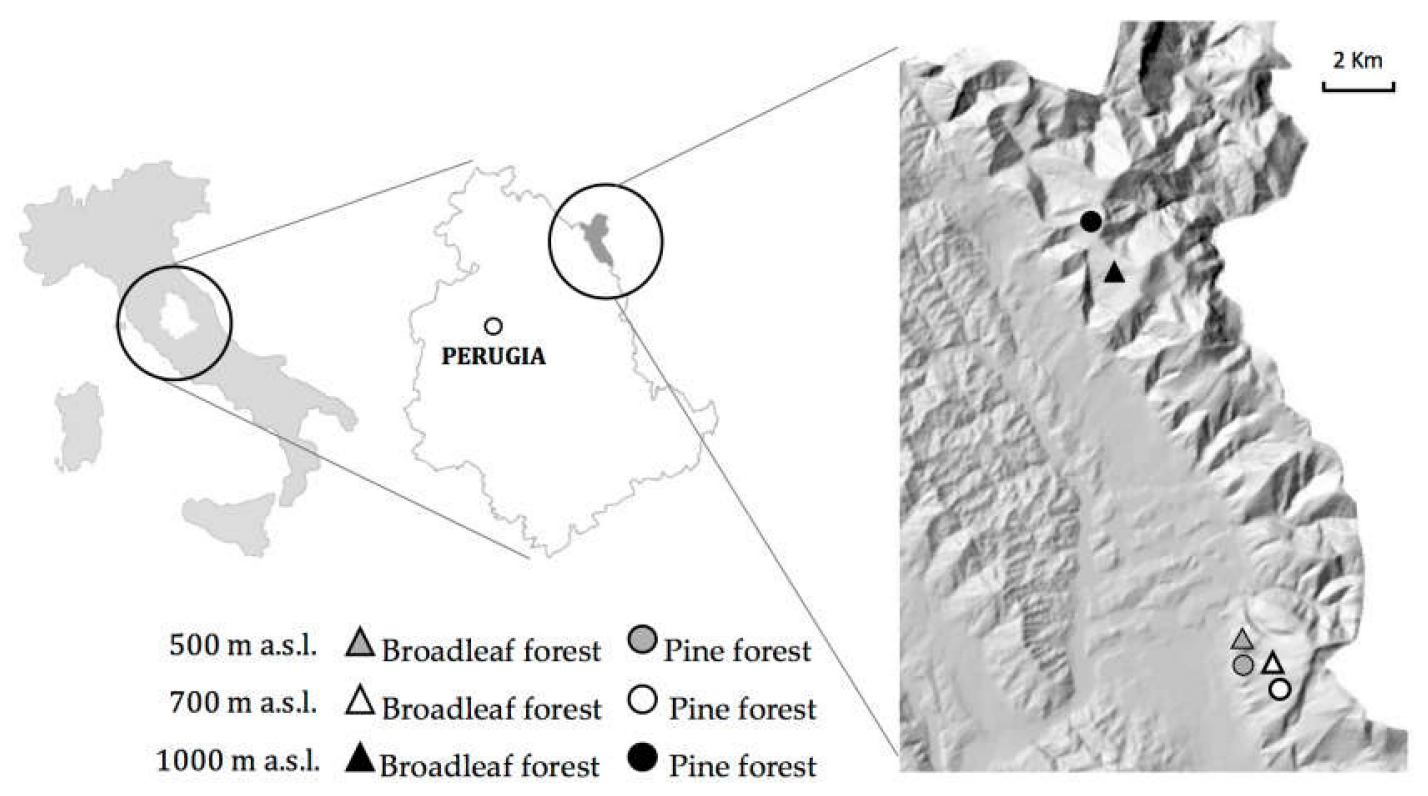

Figure 1. Map of Italy with magnification of the Umbria region and indication of the study sites.

All the broadleaf forests were coppices, although they were no longer managed for at least two decades. The air and soil (at $10 \mathrm{~cm}$ depth) temperatures were measured from October 2017 to November 2018 by means of iButton DS 1922L-F5\# temperature loggers (iButtonLink, USA). The mean soil temperatures were $12.5^{\circ} \mathrm{C}$ at $500 \mathrm{~m}, 12.1^{\circ} \mathrm{C}$ at $700 \mathrm{~m}$, and $10.0^{\circ} \mathrm{C}$ at $1000 \mathrm{~m}$ a.s.l., with a mean difference with the air temperature of about $2{ }^{\circ} \mathrm{C}$ in all sites. The mean annual precipitation usually ranges from about $1100 \mathrm{~mm}$ at $500 \mathrm{~m}$ to about $2000 \mathrm{~mm}$ at $1000 \mathrm{~m}$, the latter mostly in form of snow [28].

\subsection{Soil Sampling}

During autumn 2017, three profiles were dug within an area of $400 \mathrm{~m}^{2}$ at each altitude and forest type, for a total of 18 profiles ( 3 profiles $\times 2$ forest types $\times 3$ altitudes). All the soils developed from limestone and their morphology, which was described per Schoeneberger et al. [29], is reported in Table A1. In all sites the topsoil was characterized by well-developed Oi $(3-4 \mathrm{~cm})$ and Oe $(1-3 \mathrm{~cm})$ horizons (a thin Oa horizon was present only in the soil under broadleaf forest at $700 \mathrm{~m}$ and under pine forest at $1000 \mathrm{~m}$ ) resting on an A horizon with a moderately developed crumb structure at $500 \mathrm{~m}$ and sub-angular blocky structure at 700 and $1000 \mathrm{~m}$. Most of the soils showed a sandy loam/loamy sand texture, even though a slightly higher clay content was observed in the soil under the beech forest. In all soils the amount of rock fragments increased with depth and ranged between $30 \%$ and $60 \%$ with the exception of the beech forest, where the rock fragments were absent in $\mathrm{A}$ and $\mathrm{AB}$ horizons and reached $20 \%$ in the deepest horizon. Roots were abundant in A and AB horizons and decreased with depth, where we observed a reduction of the very fine and fine roots. As seen for rock fragments, beech forests showed the lowest number of roots. According to Soil Taxonomy [30], all the soils were classified as Typic Humustepts.

From every profile, an abundant amount of sample (about 2-3 kg) was collected from each mineral horizon constituting the solum and was stored in a portable fridge. Once in the laboratory, the soil was isolated from the roots and sieved through a $2 \mathrm{~mm}$-mesh. An aliquot of each sample was stored at $4{ }^{\circ} \mathrm{C}$ for the biochemical analyses, while the rest were air-dried at room temperature. Other than mineral samples, from each profile, aliquots of leaves or needles that comprised the most part of the Oi horizons were also collected. Once twigs and coarser plant fragments were eliminated, this organic material was air-dried and then milled until it passed through a $1 \mathrm{~mm}$ sieve. 


\subsection{Chemical and Biochemical Analyses}

The soil $\mathrm{pH}$ was determined by a combined glass-calomel electrode in water (solid: liquid ratio of 1:2.5). Total soil organic C (SOC) content was assessed by K-dichromate digestion, heating the suspension at $180^{\circ} \mathrm{C}$ for $30 \mathrm{~min}$ [31], and total $\mathrm{N}$ content was determined by a Carlo Erba EA1110 dry combustion analyzer (Carlo Erba Instruments, Milan, Italy). For the organic material (leaves and needles from Oi horizon), both $\mathrm{C}$ and $\mathrm{N}$ contents were determined using a dry combustion analyzer.

The SOC of the samples were fractionated in the following fractions: water-extractable organic $\mathrm{C}$ (WEOC), fulvic (FA-C) and humic (HA-C) acids, and not-extractable organic C (NEOC). WEOC was extracted by submerging an aliquot of each sample with distilled water (solid:liquid ratio of 1:10) and shaking for $12 \mathrm{~h}$ with an orbital shaker $(140 \mathrm{rpm})$. The mixture was centrifuged at $1400 \times g$ for $10 \mathrm{~min}$ and then filtered at $0.45 \mu \mathrm{m}$ by cellulose ester membranes. The obtained solution was analyzed for its $\mathrm{C}$ content by K-dichromate digestion. To evaluate the content of FA-C and HA-C of each sample, the solid residue of the WEOC extraction was extracted and fractionated [32] by $0.1 \mathrm{M} \mathrm{NaOH}$ (solid:liquid ratio of 1:10) under $\mathrm{N}_{2}$ atmosphere and shaking the slurry for $12 \mathrm{~h}$. The suspension was allowed to settle and the supernatant was collected after centrifugation $(15,000 \times g)$. The supernatant was acidified under continuous stirring with $9 \mathrm{M} \mathrm{H}_{2} \mathrm{SO}_{4}$ solution to $\mathrm{pH} 1$, left to stand overnight and then centrifuged $(15,000 \times g)$. The obtained raw humic and fulvic fractions were analyzed for their $\mathrm{C}$ content by K-dichromate digestion. The amount of unextractable $\mathrm{C}$ (NEOC) was calculated by subtracting the WEOC, HA-C and FA-C from the SOC content of the sample. To better assess the proportion of each fraction (WEOC, HA-C, FA-C and NEOC) to SOC for every altitude and forest type, they were expressed as percentages over SOC.

The amount of soil microbial biomass-C (Cmic) was estimated according to the fumigation-extraction protocol [33], after the samples had been incubated in glass jars for 21 days at $25^{\circ} \mathrm{C}$ and at $50 \%$ of the total water holding capacity. Briefly, aliquots of each sample were fumigated by alcohol-free chloroform $\left(\mathrm{CHCl}_{3}\right)$ vapors at $25^{\circ} \mathrm{C}$ inside a glass desiccator. After $24 \mathrm{~h}$ of fumigation, $\mathrm{CHCl}_{3}$ was removed from the samples by several evacuations. Fumigated and non-fumigated aliquots of each sample were treated with a $0.5 \mathrm{M} \mathrm{K}_{2} \mathrm{SO}_{4}$ solution (solid:liquid ratio of 1:4), shaken for $30 \mathrm{~min}$ and centrifuged. The organic $\mathrm{C}$ in the obtained solution was determined by K-dichromate wet oxidation and back-titration of the unreduced K-dichromate $[15,18]$. During the incubation period, the basal respiration was regularly measured through alkali $\left(1 \mathrm{M} \mathrm{NaOH}\right.$ solution) reaction with $\mathrm{CO}_{2}$ released from each sample and following titration with a standardized $\mathrm{HCl}$ solution after the addition of $0.5 \mathrm{M}$ $\mathrm{BaCl}_{2}$ solution. Basal respiration values were reported as the whole $\mathrm{CO}_{2}-\mathrm{C}$ released throughout the incubation period $\left(\Sigma \mathrm{CO}_{2}-\mathrm{C}\right)$. Then, in order to obtain a clearer view of soil microbial biomass and its activity, the $\Sigma \mathrm{CO}_{2}-\mathrm{C}$ : WEOC, $\Sigma \mathrm{CO}_{2}-\mathrm{C}: \mathrm{Cmic}$ and $\mathrm{Cmic}: \mathrm{SOC}$ ratios were calculated.

\subsection{Calculation of the Organic Carbon Stocks}

The stocks of organic $C$ accumulated in the upper $20 \mathrm{~cm}$ of the mineral soil for each altitude and forest type were calculated by adding the stocks of the various horizons (or a portion of them when the horizon depth crossed $20 \mathrm{~cm}$ ). The $C$ stock of each horizon was calculated by multiplying $C$ concentration, bulk density, and thickness. The bulk density was determined by the core method using steel cylinders of $493 \mathrm{~cm}^{3}$ (height: $10.8 \mathrm{~cm}$; diameter: $7.7 \mathrm{~cm}$ ). The samples collected by cylinders were dried at $105^{\circ} \mathrm{C}$ until they reached a constant weight. The bulk density was calculated from the ratio of the dried mass and volume of the soil core and corrected for the rock fragments content. Specifically, the corrected bulk density was obtained through the following calculation:

$$
\mathrm{BD}\left[\mathrm{kg} \mathrm{dm}^{-3}\right]=\left(\mathrm{m}_{\mathrm{t}}[\mathrm{kg}]-\mathrm{m}_{\mathrm{r}}[\mathrm{kg}]\right) /\left(\mathrm{V}_{\mathrm{t}}\left[\mathrm{dm}^{-3}\right]-\mathrm{V}_{\mathrm{r}}\left[\mathrm{dm}^{-3}\right]\right)
$$

where $\mathrm{BD}$ is the bulk density, $\mathrm{V}_{\mathrm{t}}$ and $\mathrm{m}_{\mathrm{t}}$ are the volume and mass, respectively, of the sample collected through the steel cylinder, and $V_{r}$ and $m_{r}$ are the volume and the mass, respectively, of the rock fragments contained inside the dried soil sample. 
Therefore, the stock of organic $\mathrm{C}$ was calculated by the following equation:

$$
\text { Stock }\left[\mathrm{Mg} \mathrm{ha}^{-1}\right]=\text { concentration }\left[\mathrm{g} \mathrm{kg}^{-1}\right] \times \mathrm{BD}\left[\mathrm{kg} \mathrm{dm}^{-3}\right] \times(1-\mathrm{Vg}) \times \text { thickness }[\mathrm{m}] \times 10
$$

where $\mathrm{Vg}$ is the volume proportion occupied by gravels in the considered horizon.

\subsection{Statistical Analysis}

According to soil horizons, two-way analysis of variance (ANOVA) was applied to analyze the effects of altitude and forest type on the measured variables. The multiple comparison tests were performed with Tukey's honest significant differences with a significance level of 0.05 . For the graphical representation of the effect of altitude and forest type on some of the measured variables, non-metric multidimensional scaling (NMDS) analyses were performed by the R package "vegan" with the dissimilarity matrix calculated by the Gower's distance. In particular, for each forest type (pine and broadleaf forests), the NMDS analysis was run on two groups of soil parameters: one composed by the data related to SOM (SOC content and its distribution in WEOC, FA-C, HA-C, and NEOC) and the other one composed by the biochemical data $\left(\mathrm{Cmic}, \Sigma \mathrm{CO}_{2}-\mathrm{C}\right.$, and $\Sigma \mathrm{CO}_{2}-\mathrm{C}: \mathrm{Cmic}, \Sigma \mathrm{CO}_{2}-\mathrm{C}: W E O C$ and Cmic:SOC ratios). Before the NMDS analysis, the data were standardized by subtracting the mean and dividing by the standard deviation. The statistical analyses were performed using the R 3.5.0 statistical software [34].

\section{Results}

\subsection{Chemical and Biochemical Soil Properties}

The values of $\mathrm{pH}_{\mathrm{H} 2 \mathrm{O}}$ were slightly alkaline in all sites with the exception of the soil located at $1000 \mathrm{~m}$ altitude under the beech forest, where the $\mathrm{pH}$ values were in the acidic field (Table 1 ) because of the presence of flint layers in the limestone from which the soil developed [35]. At the altitudes of 500 and $700 \mathrm{~m}$, the soil under broadleaf woods had a greater concentration of SOC compared to the soil under the pine forests, whereas the opposite occurred at $1000 \mathrm{~m}$ a.s.l. The largest contents of total $\mathrm{N}$ were under hop-hornbeam at $700 \mathrm{~m}$ and under pine at $1000 \mathrm{~m}$ and the $\mathrm{C}: \mathrm{N}$ ratios were generally lower in the pine forest soils than under the broadleaves (Table 1).

The soils under broadleaf forests did not display a clear SOC or total $\mathrm{N}$ trend with altitude, showing the greatest SOC and total $\mathrm{N}$ concentration in the soil under hop-hornbeam forest at $700 \mathrm{~m}$. Conversely to the broadleaf forests, SOC and, less significantly, total $\mathrm{N}$ contents increased with altitude in the soils under the pine forests. The $\mathrm{C}$ contents of decaying leaves and needles from Oi horizon did not change with altitude and were greater in the pine needles than in the leaves of the broadleaf forests (Table 2). Conversely, the $\mathrm{N}$ concentrations were greater in the leaves than in the needles and increased with altitude in both broadleaf and pine forests. Specifically, the $\mathrm{N}$ contents ranged from $13.08 \mathrm{~g} \mathrm{~kg}^{-1}$ to $17.37 \mathrm{~g} \mathrm{~kg}^{-1}$ in the leaves of the broadleaf forests, with similar values at 700 and $1000 \mathrm{~m}$, and linearly raised with altitude from $7.26 \mathrm{~g} \mathrm{~kg}^{-1}$ at $500 \mathrm{~m}$ to $12.31 \mathrm{~g} \mathrm{~kg}^{-1}$ at $1000 \mathrm{~m}$ in the pine needles (Table 2). Accordingly, the C:N ratios of the pine needles were greater than that of the leaves at each altitude along the slope. 
Table 1. Values of $\mathrm{pH}$ (in water), soil organic carbon (SOC) content, total nitrogen (TN) content and C:N ratio of the soils under the broadleaf and pine forests at 500, 700 and $1000 \mathrm{~m}$ a.s.l., Mount Cucco massif (Central Apennines, Italy). For each soil parameter and horizon, different letters indicate significant differences among vegetation types and altitudes according to Tukey's test $(p<0.05)$. Numbers in parentheses are the standard errors $(n=3)$.

\begin{tabular}{|c|c|c|c|c|c|c|c|c|c|}
\hline \multirow{2}{*}{ Horizon } & \multirow{2}{*}{ Altitude (m a.s.1.) } & \multicolumn{2}{|c|}{$\mathrm{pH}_{\mathrm{H} 2 \mathrm{O}}$} & \multicolumn{2}{|c|}{ SOC $\left(\mathrm{g} \mathrm{kg}^{-1}\right)$} & \multicolumn{2}{|c|}{$\mathrm{TN}\left(\mathrm{g} \mathrm{kg}^{-1}\right)$} & \multicolumn{2}{|c|}{ C:N ratio } \\
\hline & & Broadleaf & Pine & Broadleaf & Pine & Broadleaf & Pine & Broadleaf & Pine \\
\hline \multirow[t]{3}{*}{$\mathrm{A}$} & 500 & $7.19(0.19)^{a}$ & $7.44(0.04)^{\mathrm{a}}$ & $74.8(7.6)^{a}$ & $39.7(4.7)^{\mathrm{c}}$ & $4.47(0.51)^{a b}$ & $3.40(0.24) b c$ & $16.8(0.3)^{\mathrm{a}}$ & $11.6(0.7)^{b}$ \\
\hline & 700 & $7.45(0.02)^{\mathrm{a}}$ & $7.42(0.06)^{\mathrm{a}}$ & $108.7(12.2)^{\mathrm{a}}$ & $46.2(2.2)^{b c}$ & $6.00(0.32)^{a}$ & $3.51(0.41) b c$ & $18.0(1.2)^{\mathrm{a}}$ & $13.4(0.9)^{a b}$ \\
\hline & 1000 & $5.02(0.09)^{b}$ & $7.46(0.03)^{a}$ & $39.0(2.1)^{\mathrm{c}}$ & $69.5(6.5)^{a b}$ & $2.25(0.30)^{c}$ & $6.70(0.75)^{a}$ & $18.1(3.1)^{a}$ & $10.4(0.3)^{b}$ \\
\hline \multirow[t]{3}{*}{$\mathrm{AB}$} & 500 & $7.63(0.07)^{\mathrm{a}}$ & $7.60(0.06)^{a}$ & $44.8(3.1)^{b}$ & $28.5(2.1)^{c}$ & $3.67(0.58)^{a b}$ & $2.50(0.18)^{b c}$ & $12.6(1.5)^{\mathrm{ab}}$ & $11.4(0.1)^{\mathrm{ab}}$ \\
\hline & 700 & $7.70(0.04)^{\mathrm{a}}$ & $7.55(0.03)^{\mathrm{a}}$ & $75.5(5.9)^{\mathrm{a}}$ & $34.1(1.9) \mathrm{bc}$ & $4.58(0.24)^{\mathrm{a}}$ & $2.76(0.16)^{b}$ & $16.5(1.6)^{\mathrm{a}}$ & $12.4(0.7)^{a b}$ \\
\hline & 1000 & $5.05(0.08)^{b}$ & $7.58(0.05)^{a}$ & $19.8(1.6)^{d}$ & $47.0(5.2)^{b}$ & $1.66(0.16)^{c}$ & $4.81(0.36)^{\mathrm{a}}$ & $12.1(1.5)^{\mathrm{ab}}$ & $9.7(0.3)^{b}$ \\
\hline \multirow[t]{3}{*}{$\mathrm{Bw} 1 / \mathrm{Bw}$} & 500 & $7.75(0.06)^{\mathrm{a}}$ & $7.64(0.03)^{a}$ & $32.0(8.3)^{b c}$ & $25.6(2.1)^{b c}$ & $2.26(0.29)^{b}$ & $2.43(0.09)^{b}$ & $13.9(2.4)^{\mathrm{ab}}$ & $10.5(0.6)^{a b}$ \\
\hline & 700 & $7.78(0.05)^{\mathrm{a}}$ & $7.55(0.06)^{\mathrm{a}}$ & $67.8(7.0)^{\mathrm{a}}$ & $30.6(2.2) \mathrm{bc}$ & $3.63(0.04)^{\mathrm{a}}$ & $2.40(0.16)^{b}$ & $18.2(2.1)^{\mathrm{ab}}$ & $12.7(0.1)^{a b}$ \\
\hline & 1000 & $5.31(0.01)^{b}$ & $7.62(0.07)^{a}$ & $20.4(4.2)^{\mathrm{c}}$ & $41.8(1.7)^{\mathrm{ab}}$ & $1.26(0.05)^{\mathrm{c}}$ & $4.35(0.23)^{a}$ & $16.0(2.9)^{\mathrm{ab}}$ & $9.6(0.4)^{b}$ \\
\hline \multirow[t]{3}{*}{ Bw2 } & 500 & $7.80(0.06)^{a}$ & $7.67(0.04)^{a}$ & $34.2(6.2)^{b}$ & $25.5(3.4) b c$ & $1.95(0.37)^{\mathrm{a}}$ & $2.34(0.31)^{a}$ & $18.8(6.7)^{\mathrm{ac}}$ & $10.9(0.0)^{b c}$ \\
\hline & 700 & $7.88(0.04)^{\mathrm{a}}$ & $7.58(0.05)^{\mathrm{a}}$ & $66.8(4.5)^{\mathrm{a}}$ & $24.8(1.6)^{b c}$ & $3.75(0.69)^{\mathrm{a}}$ & $2.32(0.22)^{a}$ & $18.2(2.1)^{\mathrm{ab}}$ & $10.8(0.4)^{c}$ \\
\hline & 1000 & $5.84(0.19)^{b}$ & & $19.2(1.4)^{\mathrm{c}}$ & & $0.86(0.06)^{b}$ & & $22.6(2.1)^{\mathrm{a}}$ & \\
\hline \multirow[t]{3}{*}{$\mathrm{BC}$} & 500 & $7.93(0.07)^{\mathrm{a}}$ & & $26.4(3.0)^{b c}$ & & $1.47(0.33) b c$ & & $20.6(6.5)^{a}$ & \\
\hline & 700 & $7.86(0.04)^{\mathrm{a}}$ & $7.57(0.07)^{\mathrm{a}}$ & $49.6(5.4)^{\mathrm{a}}$ & $23.3(1.3)^{b c}$ & $3.67(0.25)^{\mathrm{a}}$ & $2.53(0.65)^{\mathrm{ab}}$ & $13.6(1.6)^{a}$ & $9.7(2.0)^{\mathrm{a}}$ \\
\hline & 1000 & $6.20(0.22)^{b}$ & $7.76(0.07)^{\mathrm{a}}$ & $12.0(3.5)^{c}$ & $38.4(3.7)^{\mathrm{ab}}$ & $0.68(0.04)^{\mathrm{c}}$ & $4.76(0.81)^{\mathrm{a}}$ & $18.0(5.9)^{\mathrm{a}}$ & $8.4(0.9)^{a}$ \\
\hline
\end{tabular}


Table 2. Carbon $(\mathrm{C})$ and nitrogen $(\mathrm{N})$ contents and C:N ratio of the decaying leaves and needles collected from the Oi horizons of the broadleaf and pine forests, respectively, at 500, 700 and $1000 \mathrm{~m}$ a.s.l., Mount Cucco massif (Central Apennines, Italy). Different letters indicate significant differences according to Tukey's test $(p<0.05)$. Numbers in parentheses are the standard errors $(n=3)$.

\begin{tabular}{ccccccc}
\hline \multirow{2}{*}{$\begin{array}{c}\text { Altitude } \\
\text { (m a.s.l.) }\end{array}$} & \multicolumn{2}{c}{$\mathbf{C}\left(\mathbf{g ~ k g}^{-\mathbf{1}}\right)$} & \multicolumn{2}{c}{$\mathbf{N}\left(\mathbf{g ~ k g}^{-\mathbf{1}}\right)$} & \multicolumn{2}{c}{ C:N ratio } \\
\cline { 2 - 7 } & Broadleaf & Pine & Broadleaf & Pine & Broadleaf & Pine \\
\hline \multirow{2}{*}{500} & 436.50 & 500.23 & 13.08 & 7.26 & 33.38 & 68.91 \\
& $(1.76)^{\mathrm{b}}$ & $(0.99)^{\mathrm{a}}$ & $(0.14)^{\mathrm{b}}$ & $(0.08)^{\mathrm{e}}$ & $(0.50)^{\mathrm{d}}$ & $(0.82)^{\mathrm{a}}$ \\
700 & 430.34 & 490.01 & 16.41 & 9.38 & 26.23 & 52.23 \\
& $(10.17)^{\mathrm{b}}$ & $(2.22)^{\mathrm{a}}$ & $(0.16)^{\mathrm{a}}$ & $(0.09)^{\mathrm{d}}$ & $(0.39)^{\mathrm{e}}$ & $(0.31)^{\mathrm{b}}$ \\
\multirow{2}{*}{1000} & 360.40 & 495.89 & 17.37 & 12.31 & 20.75 & 40.28 \\
& $(12.90)^{\mathrm{b}}$ & $(2.68)^{\mathrm{a}}$ & $(0.40)^{\mathrm{a}}$ & $(0.20)^{\mathrm{c}}$ & $(0.66)^{\mathrm{f}}$ & $(0.82)^{\mathrm{c}}$ \\
\hline
\end{tabular}

With regard to the distribution of the different organic $C$ fractions, some changes occurred in the proportion of WEOC, FA-C, HA-C and NEOC between broadleaves and pine forests at the different altitudes (Figure 2). WEOC, which ranges from about $0.5 \%$ to $2 \%$ of SOC, had the largest proportions at 700 and, to a lesser extent, at $1000 \mathrm{~m}$ in the soil under pine forest, and was not statistically different in the soil under the broadleaf forests at $500 \mathrm{~m}$ and $1000 \mathrm{~m}$. The FA-C, HA-C and NEOC fractions did not show any significant differences between broadleaf and pine forest soils at 500 and $700 \mathrm{~m}$. The soil under the beech ecosystem at $1000 \mathrm{~m}$ had a greater proportion of FA-C and HA-C compared with that of the broadleaf forests at 500 and $700 \mathrm{~m}$. In addition to this, the proportion of FA-C and HA-C in the soil under the beech forest was two- to three-fold greater than under pine forest. Consequently, at the highest altitude the proportion of NEOC over SOC was statistically lower in the soil under beech than under pine forests, at least until Bw1 horizon.
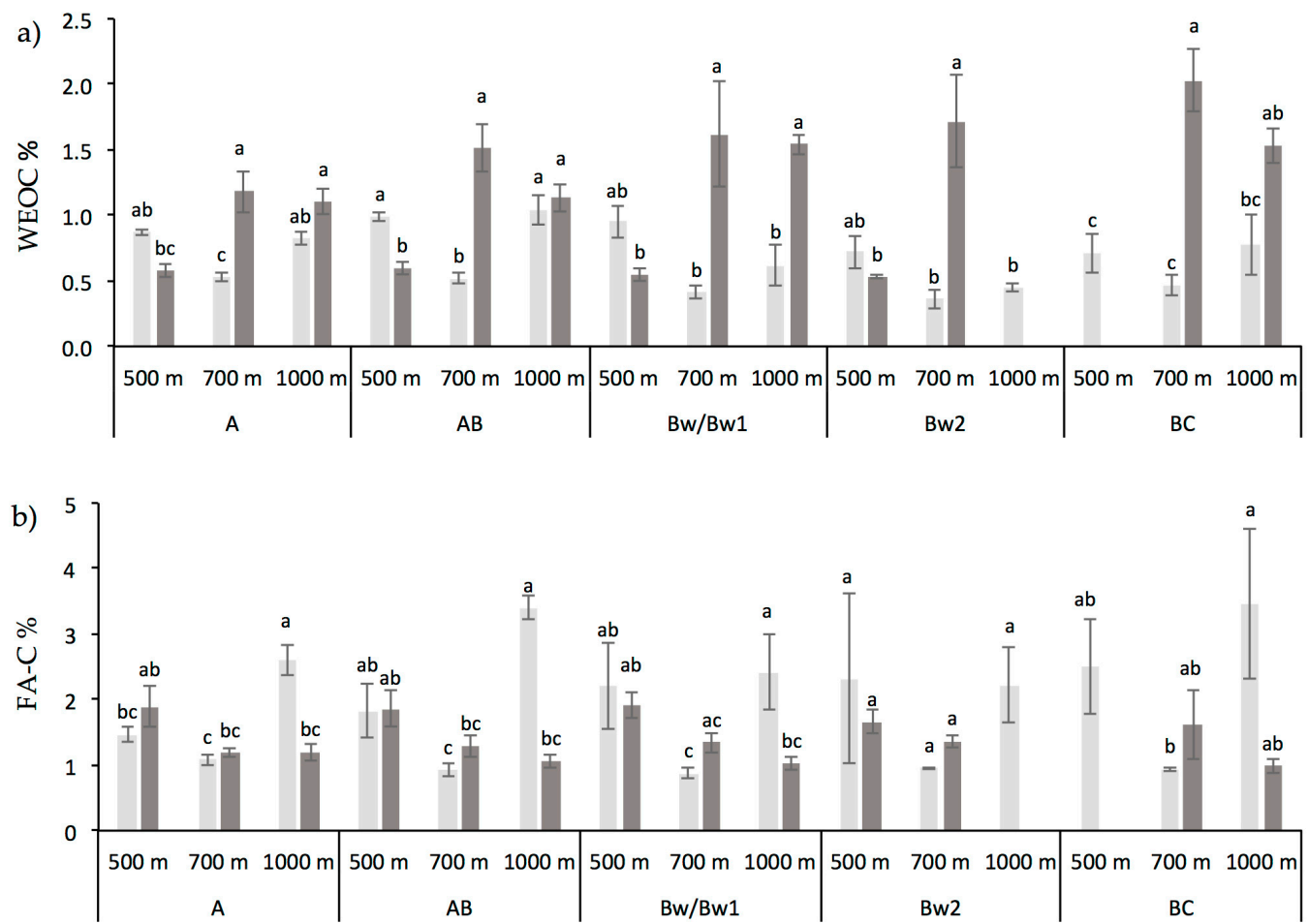

Figure 2. Cont. 

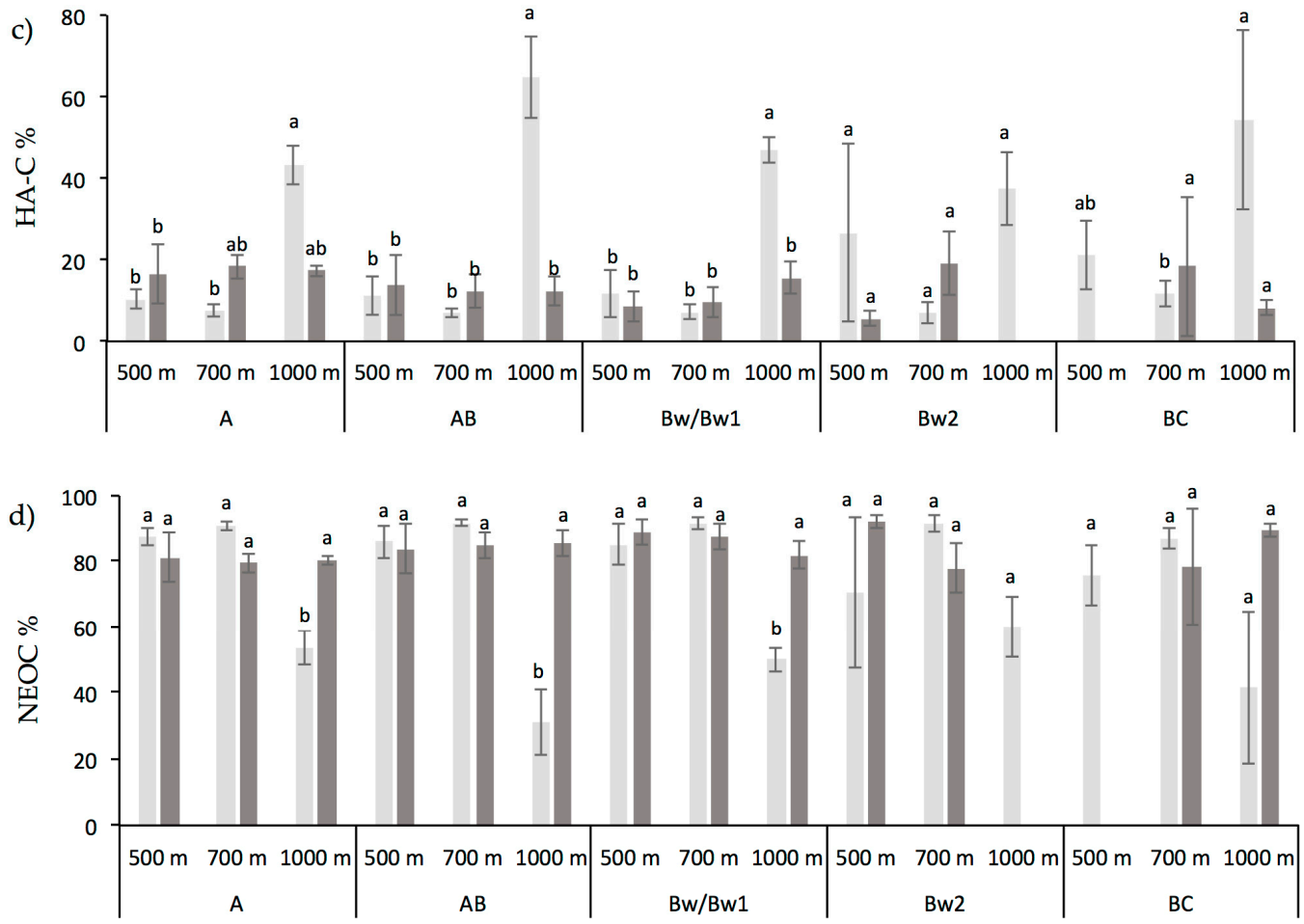

Figure 2. Percentage distribution of the soil organic carbon as (a) water-extractable organic carbon (WEOC), (b) fulvic acid carbon (FA-C), (c) humic acid carbon (HA-C) and (d) non-extractable organic carbon (NEOC) for the soils under broadleaf (light bars) and pine (dark bars) forests at 500, 700 and 1000 m a.s.l., Mount Cucco massif (Central Apennines, Italy). Error bars are the standard errors $(n=3)$. For each soil parameter and horizon, different letters indicate significant differences among vegetation types and altitudes according to Tukey's test $(p<0.05)$.

The stock of organic $C$ accumulated in the upper $20 \mathrm{~cm}$ of the mineral soil was greater under broadleaf than pine forests all along the altitudinal gradient (Figure 3).

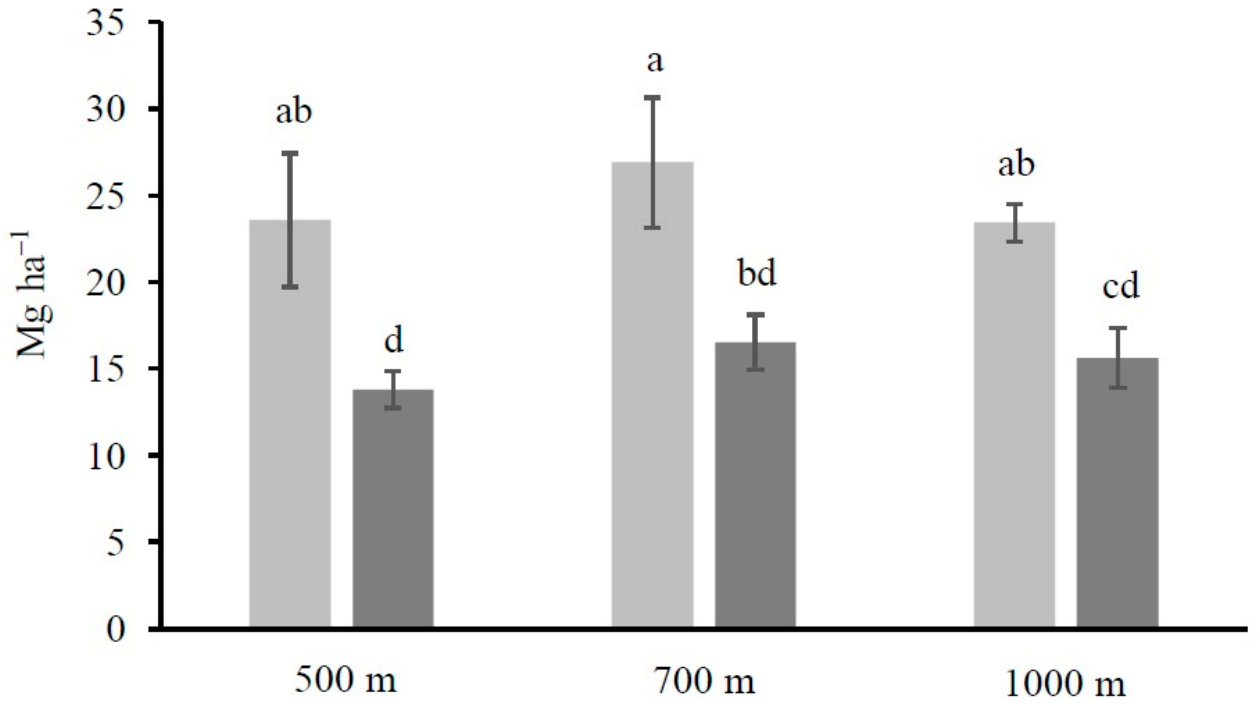

Altitude

Figure 3. Organic carbon stock at the $0-20 \mathrm{~cm}$ depth interval of the soils under the broadleaf (light bars) and pine (dark bars) forests at 500, 700 and $1000 \mathrm{~m}$ a.s.l., Mount Cucco massif (Central Apennines, Italy). Error bars are the standard errors $(n=3)$. Different letters indicate significant differences among vegetation types and altitudes according to Tukey's test $(p<0.05)$. 
As seen for SOC and total N, Cmic also did not show a trend with altitude for the soil under broadleaves, whereas an increase from $500 \mathrm{~m}$ to higher altitudes was evident for the soils under the pine forests (Table 3). It is worth noting that, considering only the upper soil horizons (A and $A B)$, at $500 \mathrm{~m}$ altitude, there was a greater concentration of $\mathrm{Cmic}$ in the soil under downy oak than in the soil under pine forests. At 700 and $1000 \mathrm{~m}$, the soil under the two forests did not show different Cmic contents in the upper horizons.

Table 3. Content of microbial biomass carbon ( $\mathrm{Cmic}$ ) and cumulative amount of $\mathrm{CO}_{2}-\mathrm{C}$ evolved during 21 days of incubation $\left(\Sigma \mathrm{CO}_{2}-\mathrm{C}\right)$ of the soils under the broadleaf and pine forests at 500, 700 and $1000 \mathrm{~m}$ a.s.l., Mount Cucco massif (Central Apennines, Italy). For each soil parameter and horizon, different letters indicate significant differences among vegetation types and altitudes according to Tukey's test $(p<0.05)$. Numbers in parentheses are the standard errors $(n=3)$.

\begin{tabular}{|c|c|c|c|c|c|}
\hline \multirow{2}{*}{ Horizon } & \multirow{2}{*}{ Altitude (m a.s.1.) } & \multicolumn{2}{|c|}{ Cmic (mg kg-1) } & \multicolumn{2}{|c|}{$\Sigma \mathrm{CO}_{2}-\mathrm{C}\left(\mathrm{mg} \mathrm{kg}^{-1}\right)$} \\
\hline & & Broadleaf & Pine & Broadleaf & Pine \\
\hline \multirow[t]{3}{*}{ A } & 500 & $579(37)^{c}$ & $308(31) \mathrm{d}$ & $1819(179)^{\mathrm{a}}$ & $1111(124) b c$ \\
\hline & 700 & $1059(65)^{a}$ & $831(39)^{a b}$ & $1385(134)^{a b}$ & $1037(36)^{b c}$ \\
\hline & 1000 & $688(35)^{b c}$ & $836(49)^{a b}$ & $607(81)^{d}$ & $826(73)^{c}$ \\
\hline \multirow[t]{3}{*}{$\mathrm{AB}$} & 500 & $488(19)^{a b}$ & $199(38)^{c}$ & $1387(93)^{\mathrm{a}}$ & $825(58) b c$ \\
\hline & 700 & $750(93)^{a}$ & $752(66)^{a}$ & $1169(49)^{a b}$ & $788(79)^{c}$ \\
\hline & 1000 & $363(77) b c$ & $597(86)^{a b}$ & $349(105)^{d}$ & $550(62)^{c d}$ \\
\hline \multirow[t]{3}{*}{ Bw1/Bw } & 500 & $474(82)^{a b}$ & $310(86)^{b}$ & $875(62)^{a}$ & $726(103)^{a}$ \\
\hline & 700 & $568(58)^{a b}$ & $766(48)^{a}$ & $754(107)^{a}$ & $849(68)^{a}$ \\
\hline & 1000 & $290(68)^{b}$ & $449(72)^{b}$ & $210(33)^{b}$ & $530(90)^{a}$ \\
\hline \multirow[t]{3}{*}{ Bw2 } & 500 & $162(53)^{b}$ & $169(79)^{b}$ & $657(33)^{a}$ & $570(102)^{a}$ \\
\hline & 700 & $470(0)^{a b}$ & $625(51)^{\mathrm{a}}$ & $621(87)^{a}$ & $644(14)^{a}$ \\
\hline & 1000 & $287(82)^{b}$ & & $125(23)^{b}$ & \\
\hline \multirow[t]{3}{*}{$\mathrm{BC}$} & 500 & $134(42)^{\mathrm{c}}$ & & $612(12)^{a b}$ & \\
\hline & 700 & $470(37)^{b}$ & $655(16)^{a}$ & $788(114)^{a}$ & $630(54)^{a b}$ \\
\hline & 1000 & $127(54)^{\mathrm{c}}$ & $262(76)^{b}$ & $76(14)^{c}$ & $466(54)^{b}$ \\
\hline
\end{tabular}

The amount of $\mathrm{CO}_{2}-\mathrm{C}$ released during the basal respiration experiment $\left(\Sigma \mathrm{CO}_{2}-\mathrm{C}\right)$ differed only in the upper $\mathrm{A}$ and $\mathrm{AB}$ horizons for the soils at 500 and $700 \mathrm{~m}$ and, specifically, $\Sigma \mathrm{CO}_{2}-\mathrm{C}$ values were higher for the downy oak and hop-hornbeam than for the pine forests (Table 3). At $1000 \mathrm{~m}$, a larger respiration was generally assessed for the soil under pine forests compared to that under beech forests. The $\Sigma \mathrm{CO}_{2}-\mathrm{C}:$ WEOC ratio (Figure 4) showed a significant difference between the soil under the two forest types only at $500 \mathrm{~m}$ altitude, where the soil under pine forests had values greater than that under downy oaks. The $\Sigma \mathrm{CO}_{2}-\mathrm{C}: W E O C$ ratio tended to decrease with altitude for all the soils and reached the lowest values at $1000 \mathrm{~m}$. At every selected altitude, the $\Sigma \mathrm{CO}_{2}-\mathrm{C}: \mathrm{Cmic}$ ratio (Figure 4) did not show differences between the two forest soils, but it decreased sharply from $500 \mathrm{~m}$ to 700 and $1000 \mathrm{~m}$ altitude. The Cmic:SOC ratio (Figure 4) was similar for the soil under broadleaves and pine forests at 500 and $1000 \mathrm{~m}$, but it was higher under pine than under hop-hornbeam forests at $700 \mathrm{~m}$. 

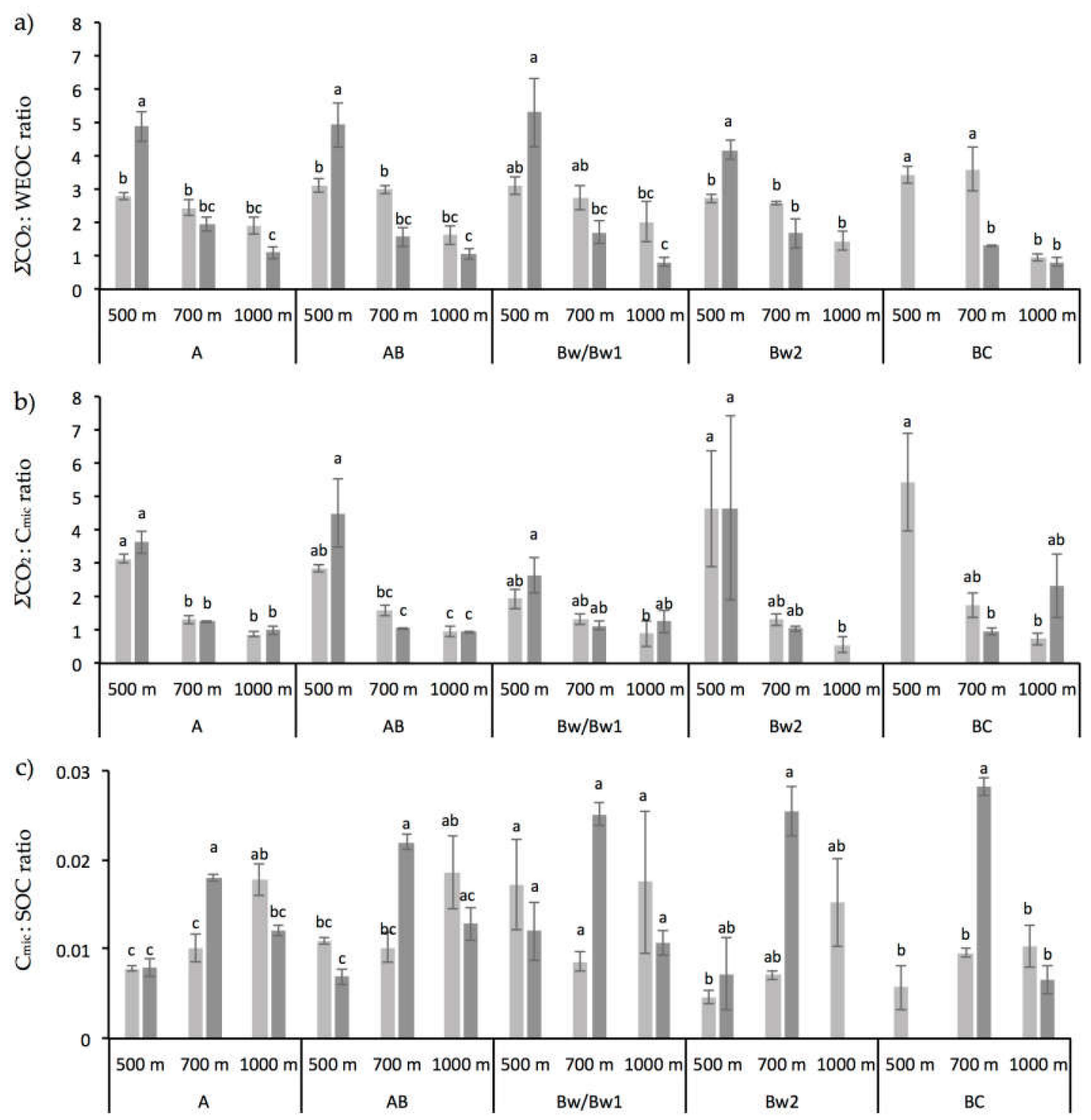

Figure 4. (a) Cumulative basal respiration $\left(\Sigma \mathrm{CO}_{2}-\mathrm{C}\right)$ to water-extractable organic carbon ratio ( $\Sigma \mathrm{CO}_{2}$-C:WEOC ratio), (b) $\Sigma \mathrm{CO}_{2}-\mathrm{C}$ to microbial biomass carbon ( $\mathrm{Cmic}$ ) ratio $\left(\Sigma \mathrm{CO}_{2}-\mathrm{C}: \mathrm{Cmic}\right.$ ratio), and (c) Cmic to soil organic carbon ratio (Cmic:SOC ratio) for the soils under broadleaf (light bars) and pine (dark bars) forests at 500, 700 and 1000 m a.s.l., Mount Cucco massif (Central Apennines, Italy). Error bars are the standard errors $(n=3)$. For each soil parameter and horizon, different letters indicate significant differences among vegetation types and altitudes according to Tukey's test $(p<0.05)$.

\subsection{Non-Metric Multidimensional Scaling (NMDS) Analyses}

The plots of the NMDS analyses performed on SOC content and on percentage distribution of the soil organic matter fractions showed a different behavior between broadleaf and pine forest soils (Figure $5 a, b$ ). While the NMDS plot of the broadleaf forests (stress $=0.118$ ) showed a rather complete overlapping of the ellipses relative to the three altitudes (Figure 5a), for the soils under pine an evident dissimilarity occurred between the forests at low altitude $(500 \mathrm{~m})$ and those at $\mathrm{mid}(700 \mathrm{~m})$ and high $(1000 \mathrm{~m})$ altitude (stress $=0.157)$ (Figure $5 \mathrm{~b}$ ). This dissimilarity between sites at $500 \mathrm{~m}$ and sites at 700 and $1000 \mathrm{~m}$ occurred along the NMDS2 axis and this separation appeared to be driven mainly by the WEOC component whose vector was aligned with the NMDS2 axis and had the highest value in the NMDS2 axis (Figure S1 of Supplementary Materials). 


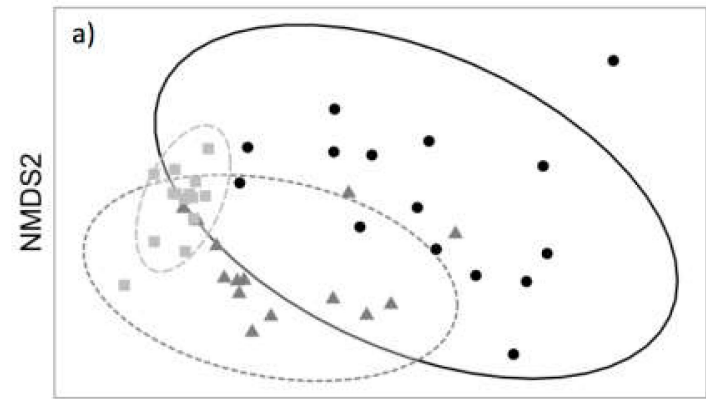

NMDS1

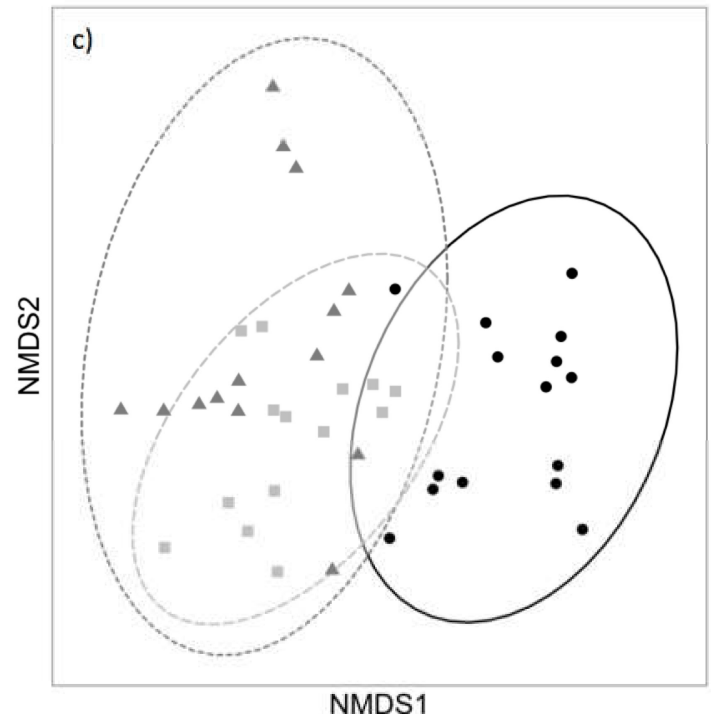

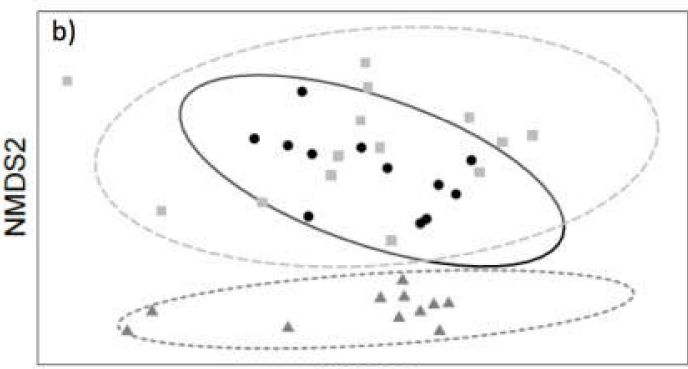

NMDS1

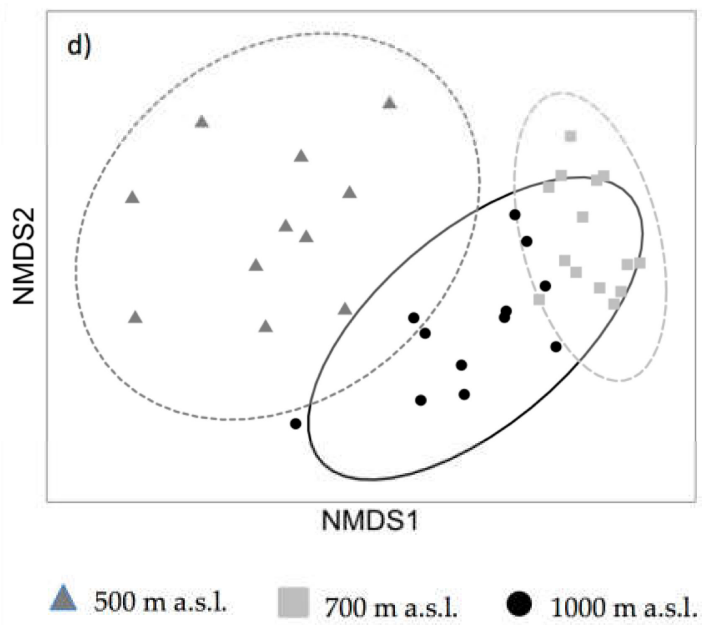

Figure 5. Two-dimensional non-metric multidimensional scaling (NMDS) plots of SOC and its distribution in WEOC, FA-C, HA-C and NEOC fractions for the soils under broadleaf (a) and pine (b) forests, and NMDS plots of $\Sigma \mathrm{CO} 2-\mathrm{C}, \mathrm{Cmic}, \Sigma \mathrm{CO} 2-\mathrm{C}$ :WEOC ratio, $\Sigma \mathrm{CO} 2-\mathrm{C}: \mathrm{Cmic}$ ratio and Cmic:SOC ratio for the soils under broadleaf (c) and pine (d) forests, respectively, at 500, 700 and $1000 \mathrm{~m}$ a.s.l., Mount Cucco massif (Central Apennines, Italy). Circle lines in NMDS plot are 95\% confidence ellipses. SOC: soil organic carbon; WEOC: water-extractable organic carbon; FA-C: fulvic acid carbon; HA-C: humic acid carbon; NEOC: non-extractable organic carbon; $\Sigma \mathrm{CO} 2-\mathrm{C}$ : cumulative basal respiration; Cmic: microbial biomass carbon.

The NMDS analysis performed on the soil biochemical data (Figure $5 c, d$ ) (stress $=0.069$ and 0.105 , respectively) showed a fairly good dissimilarity among the altitudes for both broadleaf and pine forests, as only a slight overlapping of the ellipses relative to the forests at $500 \mathrm{~m}$ and those at $1000 \mathrm{~m}$ was observed. In addition, the sites at $700 \mathrm{~m}$ had a similar behavior to that at $1000 \mathrm{~m}$ and at $500 \mathrm{~m}$ for the pine and the broadleaf forests, respectively. These similarities and dissimilarities occurred along the NMDS1 axis and they were mainly driven by $\mathrm{Cmic}$ and $\mathrm{Cmic}: \mathrm{SOC}$ ratios for the pine forest, and by $\Sigma \mathrm{CO}_{2}-\mathrm{C}$ and $\Sigma \mathrm{CO}_{2}-\mathrm{C}: \mathrm{WEOC}$ ratios for the broadleaf forests (Figure S1 of Supplementary Materials). In particular, the contribution of these variables to the dissimilarities occurring along altitude in both forest ecosystems were indicated by the high values and alignment of their vector with NMDS1 axis (Figure S1 of Supplementary Materials). 


\section{Discussion}

\subsection{Altitude and Vegetation Effects on Soil Organic Carbon and Its Fractions Distribution}

As displayed by the NMDS analysis (Figure $5 a, b$ ), the behavior showed by the soil under the pine ecosystem along the altitudinal gradient was different from that under the broadleaf forests, confirming the important role played by vegetation on the SOC and on its fractions distribution [36]. Our results showed that the SOC content along the slope, from 500 to $1000 \mathrm{~m}$, did not follow the same trend for both broadleaf and pine forests. The content of SOC of the soils covered by broadleaves did not show a clear increasing trend with altitude, indicating that vegetation traits strongly influence belowground processes $[21,37,38]$. In particular, it has been reported that leaf stoichiometry affects litter decomposability, e.g., [39]. To this regard, because of the higher degradability of the organic tissues with a low $\mathrm{C}: \mathrm{N}$ ratio, the lower $\mathrm{C}: \mathrm{N}$ ratio of the European hop-hornbeam leaves than that of the downy oak could explain the greater SOC concentration that occurred at $700 \mathrm{~m}$ compared to that at $500 \mathrm{~m}$. However, the vegetation effect is not sufficient to explain the lowest amount of SOC found in the soil under the beech forest. At this site, the SOC content can be affected, other than by a decline in plant productivity due to the low temperature, by the acidic soil $\mathrm{pH}$ which reduces the surface charge of minerals [40] and limits the organo-mineral interactions. This fact was supported by the lowest proportion of NEOC, mostly comprised of the mineral-associated organic matter $[39,41]$, and the largest humic component in the soil under beech forests (Figure 1), indicating a low capacity of the minerals to strongly adsorb organic molecules. The lower SOC content of the soil under pine forests compared to that under the broadleaf forests, at least at 500 and $700 \mathrm{~m}$, was attributed to the slow decay rate of the pine needles due to their sclerophyllous trait and higher C:N ratio [25].

Conversely to the soils under broadleaf forests, the soils of the pine forests showed an increase of SOC concentrations with increasing altitude. Since the plant species is the same along the altitudinal gradient, the rising of SOC contents with altitude was mostly attributed to the lowering of soil microbial activity (as indicated also by the decreasing trend of $\Sigma \mathrm{CO}_{2}-\mathrm{C}: \mathrm{WEOC}$ and $\Sigma \mathrm{CO}_{2}-\mathrm{C}: \mathrm{Cmic}$ ratios). In particular, the low air and soil temperatures at higher altitudes (the soil temperature decreased by about $2.5^{\circ} \mathrm{C}$ from 500 to $1000 \mathrm{~m}$ a.s.1.), although diminishing the plant productivity [42], reduce the activity of the soil microbial community $[3,4,11]$ and therefore promote SOC accumulation. The increase of SOC in the mineral soil could also be favoured by the reduction of the C:N ratio of the pine needles along the slope (from 68.91 at $500 \mathrm{~m}$ to 40.28 at $1000 \mathrm{~m}$ ). The marked increase of the N concentration of the needles (Table 2), according to Gebauer et al., [43] and Liu et al. [44], was ascribed to a greater $\mathrm{N}$ assimilation efficiency of the plants at a higher altitude as a response to the short growing season and to the adverse environmental conditions. As a consequence of the increasing SOC concentration with altitude occurring in the soils under the pine ecosystem, and the low SOC concentration in the soil under beech forests, the organic $C$ stocks in the upper $20 \mathrm{~cm}$ were greater under broadleaves than under the pine ecosystem at 500 and $700 \mathrm{~m}$, whereas a similar amount of $C$ was stored in the soils covered by beech and pine forests at $1000 \mathrm{~m}$ altitude. However, the organic $C$ stock in the upper $20 \mathrm{~cm}$ was greater in broadleaf than in pine ecosystems all along the slope. At 500 and $700 \mathrm{~m}$, this was due to the higher SOC concentration of the soils under the broadleaf compared to that under pine forests. At $1000 \mathrm{~m}$, the absence of rock fragments in the upper horizons of the soil under beech forests (Table A1) had a greater weight than the SOC concentration, which was lower compared to that of the soil under pine forests, in the calculation of the organic $\mathrm{C}$ stock.

With the exception of NEOC and humic substance distributions occurring in the soil under beech forests, few significant changes with altitude and vegetation occurred for FA-C, HA-C and NEOC proportions over SOC. Conversely, WEOC, which is the most mobile and labile SOC fraction, had different behaviors in the broadleaf and pine forest soils along the slope. In particular, the absence of an altitudinal trend in the soils under broadleaf ecosystems can be explained again by the traits of the forest floor produced by the different plant species at each altitude. Indeed, the characteristics of the litter, which is considered the principal source of WEOC [45] together with rhizodepositions [18], 
can affect the forest floor decomposability and the quality of the degradation products at the different altitudes [46]. In the soils under pine forests the impact of altitude/temperature would not be masked by the plant species effect (which was specific at each altitude for the broadleaves), and the WEOC proportion tended to rise with altitude according to many papers, e.g., $[18,47,48]$ that reported an increase of soluble organic matter with increasing altitude. Specifically, in our case, WEOC increased from 500 to greater altitude (no difference was observed between 700 and $1000 \mathrm{~m}$ ) likely due to the lower soil microbial activity (lower $\Sigma \mathrm{CO}_{2}-\mathrm{C}: \mathrm{WEOC}$ and $\Sigma \mathrm{CO}_{2}-\mathrm{C}: \mathrm{Cmic}$ ratios) occurring at 700 and $1000 \mathrm{~m}$ compared to $500 \mathrm{~m}$. Since WEOC represents the most labile and readily available C source for the soil microbial community [49], the lower microbial activity, and therefore the lesser amount of WEOC used by microorganisms for their own maintenance, at 700 and $1000 \mathrm{~m}$ compared to $500 \mathrm{~m}$ might explain the observed WEOC trend.

\subsection{Altitude and Vegetation Effects on Biochemical Soil Properties}

The key role of altitude, and therefore the related soil and air temperature, on the main biochemical soil properties measured in the present study was supported by the NMDS analysis (Figure 5c,d) which showed a similar altitudinal differentiation for both broadleaf and pine forests. The only exception were the different trends of Cmic content showed by the two forest types that were likely due to a vegetation effect [50], since the quantity and quality of forest floor are crucial drivers that affect the soil microbial biomass [51]. Further, previous studies indicate that $\mathrm{Cmic}$ is positively related to soil organic $\mathrm{C}$ content [52] and $\mathrm{pH}$ [53], and negatively related to soil $\mathrm{C}: \mathrm{N}$ ratio [53]. In our case, Cmic content of the soils under pine forests mirrored the trend of WEOC (Figure 2), which is the most bioavailable source of energy for soil microorganisms [54,55]. In the broadleaf forests, the Cmic content mostly followed the SOC contents along the slope. For the soil under beech forests, however, the low Cmic value was attributed, other than to the low SOC content, to the acidic $\mathrm{pH}$ of the soil that ranged from about 5.0 to 6.2 along the profile. A pH value less than 6.2 leads to a reduction of the microbial growth and turnover rates [56], whereas when $\mathrm{pH}$ reaches values less than 5.2, it even limits the use of labile organics by soil microbes $[57,58]$. The depressing effect of soil acidity on the use of labile organics by the microbial community, and the reduced WEOC availability due to both low soil pH and limited root abundance $[59,60]$ might also explain the lack of differences in the WEOC proportions between the beech and the other broadleaf forests along the altitudinal gradient.

The general decrease of $\Sigma \mathrm{CO}_{2}-\mathrm{C}$ with altitude was attributed, according to several studies (e.g., [56,57]), to a lower activity of the microbial community with decreasing soil temperature. However, $\Sigma \mathrm{CO}_{2}-\mathrm{C}: W E O C$ and $\Sigma \mathrm{CO}_{2}-\mathrm{C}: \mathrm{Cmic}$ ratios (Figure 3) can better describe the activity of the soil microbial community than $\mathrm{Cmic}$ and $\Sigma \mathrm{CO}_{2}-\mathrm{C}$ values. Although some differences between the forest soils at each altitude occurred, there is evidence of similar general diminishing trends of the ratios with altitude for both broadleaf and pine forests. In particular, the lower $\Sigma \mathrm{CO}_{2}-\mathrm{C}: \mathrm{WEOC}$ and $\Sigma \mathrm{CO}_{2}-\mathrm{C}: \mathrm{Cmic}$ ratios at 700 and $1000 \mathrm{~m}$, compared to that of the sites at $500 \mathrm{~m}$, suggested a better substrate use efficiency of the microbial community harboring the soils at high altitude [61]. Specifically, the limited respiration per unit of WEOC, and therefore the greater conversion of the labile organic substrates into new biomass, can be considered the result of a greater $C$ sequestration by the soil microbial community at higher altitudes. The similar trend of $\Sigma \mathrm{CO} 2-\mathrm{C}, \mathrm{d} \Sigma \mathrm{CO} 2-\mathrm{C}: \mathrm{WEOC}$ and $\Sigma \mathrm{CO} 2-\mathrm{C}: \mathrm{Cmic}$ ratios for both broadleaf and pine forests along the studied altitudinal gradient suggests that the temperature drives the microbial activity more than the vegetation.

\section{Conclusions}

This study aimed to assess the relative effects of multiple environmental factors (altitude-dependent temperature and vegetation) on SOC and soil microbial biomass and activity, along two contiguous toposequences ranging from 500 to $1000 \mathrm{~m}$ on a calcareous massif (Mount Cucco, Apennines chain, central Italy) and covered by broadleaf forests and pine reforestation, respectively. 
The absence of an altitudinal/thermal trend for SOC contents and stocks under broadleaf forests, where a specific dominant species occurred at each altitude, indicates that plant cover and the resulting forest floor traits affect the degradation processes and the organic $\mathrm{C}$ accumulation into the mineral soil of the Mount Cucco massif. Conversely, along the toposequence covered by the pine forests, where the plant species effect was absent, the climatic impact induced by the altitude on SOC was evident. With regard to the soil microbial community, although the size of the soil microbial biomass followed the SOC contents along the slope, both broadleaf and pine forest soils showed a similar diminishing trend with altitude of $\Sigma \mathrm{CO}_{2}-\mathrm{C}, \Sigma \mathrm{CO}_{2}-\mathrm{C}: W E O C$ and $\Sigma \mathrm{CO}_{2}-\mathrm{C}: \mathrm{Cmic}$ ratios, suggesting the substrate use efficiency of the microbial community improved at high altitudes, where the demand of energy and available substrates for the soil microbes maintenance is low. From an ecological point of view, our findings suggest a high potential of the soils at higher altitudes, compared to those at lower ones, to favor the incorporation of the labile form of $\mathrm{C}$ into the soil microbial biomass.

In conclusion, though also edaphic (e.g., soil $\mathrm{pH}$ ) and site-specific microclimatic conditions may play a role, our findings indicate that the altitude-dependent soil temperature and vegetation have a distinct effect on SOC and soil microbes. Specifically, while vegetation controls more than temperature the SOC amount and pool distribution, the temperature appears to be the main driver on the activity of the soil microbial community.

Supplementary Materials: The following are available online at http://www.mdpi.com/1999-4907/11/6/710/s1, Figure S1: Representation of variable scores, as vectors, obtained from the non-metric multidimensional scaling (NMDS) analyses performed on SOC and its distribution in WEOC, FA-C, HA-C and NEOC fractions for the soils under broadleaf (a) and pine (b) forests, and on $\Sigma C O 2-C, C$ mic, $\Sigma C O 2-C$ :WEOC ratio, $\Sigma C O 2-C$ :Cmic ratio and Cmic:SOC ratio for the soils under broadleaf (c) and pine (d) forests, respectively, at 500, 700 and $1000 \mathrm{~m}$ a.s.l., Mount Cucco massif (Central Apennines, Italy). SOC: soil organic carbon; WEOC: water-extractable organic carbon; FA-C: fulvic acid carbon; HA-C: humic acid carbon; NEOC: non-extractable organic carbon; $\Sigma$ CO2-C: cumulative basal respiration; Cmic: microbial biomass carbon.

Author Contributions: Conceptualization, L.M.; formal analysis, L.M. and M.D.F.; investigation, L.M., M.D.F. and A.L.; writing-original draft preparation, L.M. and M.D.F.; writing-review and editing, L.M., M.D.F. and A.A.; visualization, L.M. and M.D.F.; supervision, A.A.; Project administration, A.A. All authors have read and agreed to the published version of the manuscript.

Acknowledgments: We are grateful to Daniela Gigante for her help in the vegetation survey of the study areas and we thank Emanuela Grima for the English language editing.

Conflicts of Interest: The authors declare no conflict of interest. 


\section{Appendix A}

Table A1. Main descriptive elements of soil profiles developed under the broadleaf forests and the areas reforested with black pine (Pinus nigra J.F. Arnold) at 500, 700 and $1000 \mathrm{~m}$ a.s.l., Mount Cucco massif (Central Apennines, Italy). For symbols see legend.

\begin{tabular}{|c|c|c|c|c|c|c|c|c|c|c|}
\hline Horizon & Depth & Colour $^{a}$ & Structure ${ }^{b}$ & Consistence $^{c}$ & Texture $^{\mathrm{d}}$ & Roots ${ }^{e}$ & Thickness & Boundary ${ }^{f}$ & Rock Fragments $g$ & $\begin{array}{c}\text { Other } \\
\text { Observations }\end{array}$ \\
\hline & $\mathrm{cm}$ & & & & & & $\mathrm{cm}$ & & & \\
\hline
\end{tabular}

Altitude $\approx 500$ m a.s.l. $\left(43^{\circ} 16^{\prime} 57^{\prime \prime} \mathrm{N}, 12^{\circ} 45^{\prime} 39^{\prime \prime} \mathrm{E}\right)$; exposure: W; slope: $\approx 20 \%$. Soil: loamy-skeletal, mixed, mesic, Typic Humustepts [30]

Vegetation: Upper stratum: Quercus pubescens Willd.-Lower stratum: Fraxinus ornus L., Ostrya carpinifolia Scop.-Understory: Brachypodium rupestre (Host) Roem. E Schult, Lonicera caprifolium L, Cotynus cogygria Scop., Citisus sessilifolius L. 1753, Asparagus acutifolius L., Carex flacca Schreb. seedlings.

Quercus leafs with twigs and cupules

\begin{tabular}{|c|c|c|c|c|c|c|c|c|c|}
\hline Oi & $5-2$ & & & & & & & & \\
\hline $\mathrm{Oe}$ & $2-0$ & & & & & & & & \\
\hline A & $0-12$ & 5YR 4/4 & $2 \mathrm{f} \mathrm{cr}$ & $\mathrm{s}, \mathrm{ps}$ & sl & $3 \mathrm{mi}, \mathrm{vf}, \mathrm{f}, \mathrm{m}$ & $5-12$ & $\mathrm{CW}$ & $40 \% \mathrm{Mgr}$ \\
\hline $\mathrm{AB}$ & $12-24$ & 5YR 4/6 & $2 \mathrm{f} \mathrm{sbk}$ & ss, ps & sl & $3 \mathrm{mi}, \mathrm{vf}, \mathrm{f}, \mathrm{m}$ & $7-12$ & $\mathrm{cW}$ & $50 \% \mathrm{Mgr}$ \\
\hline Bw1 & 24-35 & 2.5YR4/6 & $2 \mathrm{fm} \mathrm{sbk}$ & so, po & sl & $3 \mathrm{mi}, \mathrm{vf}, \mathrm{f}, 1 \mathrm{~m}$ & 11 & CS & $50 \%$ Cgr, \\
\hline Bw2 & $35-48$ & $2.5 Y R 4 / 6$ & $1 \mathrm{fm} \mathrm{sbk}$ & ss, ps & sl & $2 \mathrm{vf}, \mathrm{f}, 1 \mathrm{~m}$ & 13 & $\mathrm{Cs}$ & $60 \%$ VCgr \\
\hline $\mathrm{BC}$ & $48-61+$ & 5YR4/8 & $1 \mathrm{fm} \mathrm{sbk}$ & ss, ps & sl & $1 \mathrm{f}, \mathrm{m}$ & - & - & $60 \% \mathrm{VCgr}$ \\
\hline
\end{tabular}

Vegetation: Upper stratum: Pinus nigra J.F. Arnold—Lower stratum: Fraxinus ornus L., Quercus pubescens L.—Understory: Brachypodium rupestre (Host) Roem. E Schult, Spartium

$\begin{array}{ccccccccc}\text { Oi } & 5-2 & & & & & \\ \text { Pinus needles, with } \\ \text { twigs and cones }\end{array}$


Table A1. Cont.

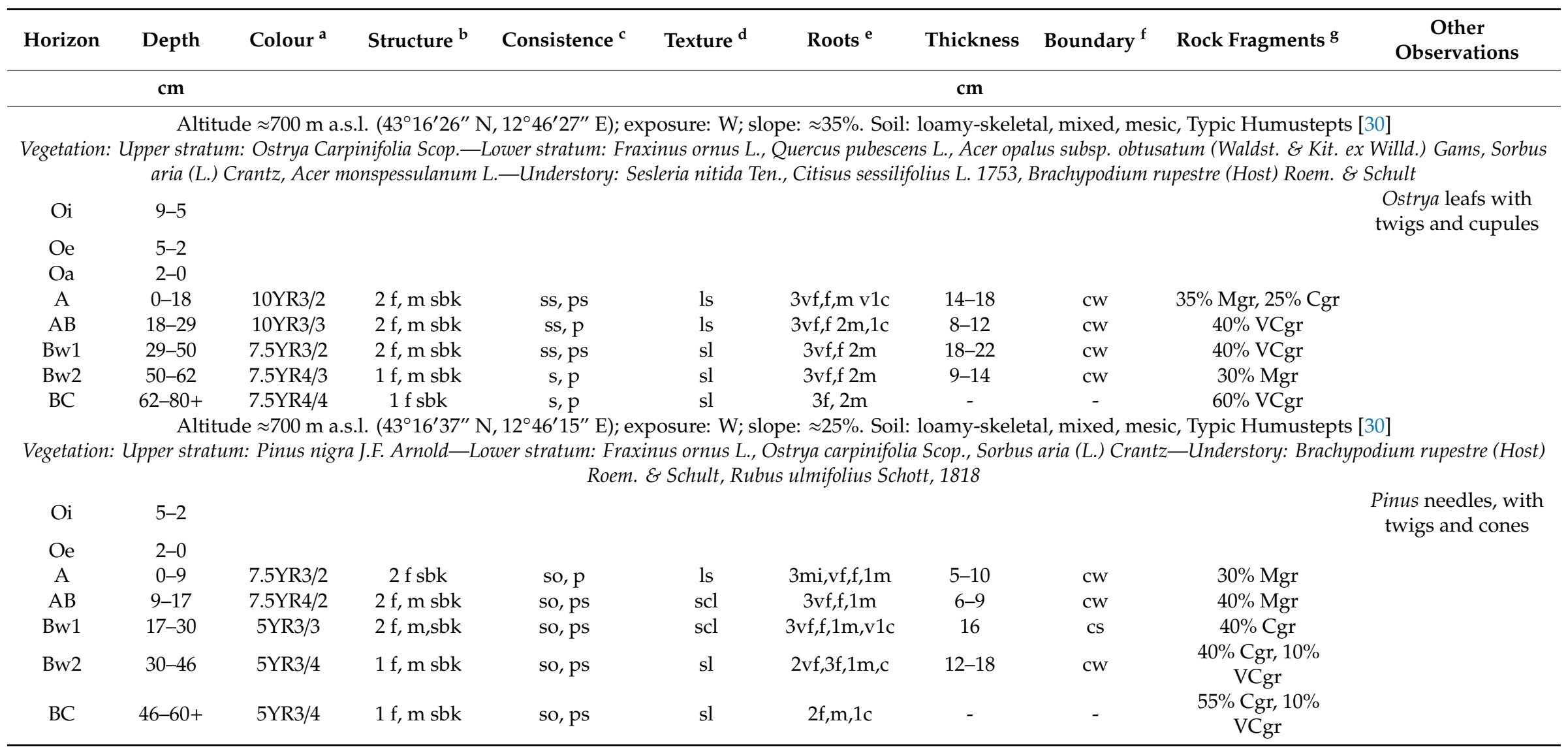


Table A1. Cont.

\begin{tabular}{|c|c|c|c|c|c|c|c|c|c|c|}
\hline Horizon & Depth & Colour ${ }^{a}$ & Structure ${ }^{b}$ & Consistence $^{c}$ & Texture $^{\mathrm{d}}$ & Roots $^{e}$ & Thickness & Boundary ${ }^{f}$ & Rock Fragments $\mathrm{g}$ & $\begin{array}{c}\text { Other } \\
\text { Observations }\end{array}$ \\
\hline & $\mathrm{cm}$ & & & & & & $\mathrm{cm}$ & & & \\
\hline
\end{tabular}

Altitude $\approx 1000$ m a.s.l. $\left(43^{\circ} 23^{\prime} 36^{\prime \prime} \mathrm{N}, 12^{\circ} 42^{\prime} 31^{\prime \prime}\right.$ E); exposure: $\mathrm{W}$; slope: $\approx 25 \%$. Soil: loamy, mixed, mesic, Typic Humustepts [30]

Vegetation: Upper stratum: Fagus sylvatica L.—Lower stratum: Acer campestre L., Quercus cerris L., Prunus avium L.—Understory: Aegopodium podagraria L., Arctium lappa L., 1753

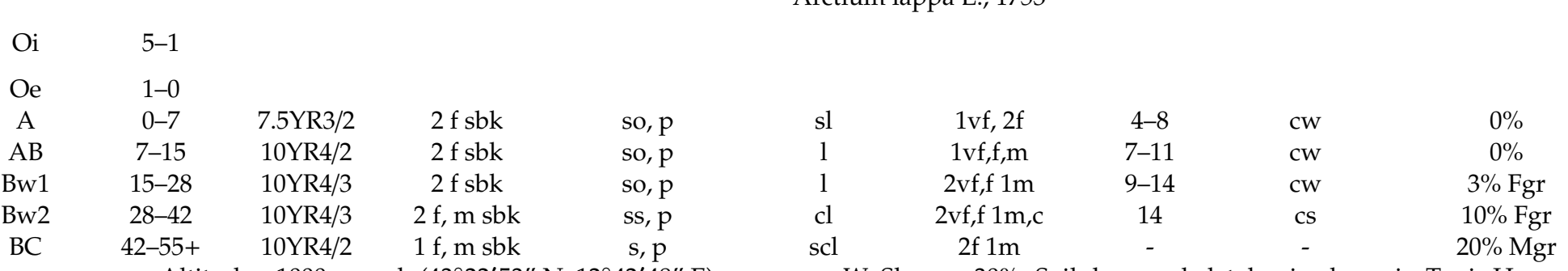

Altitude $\approx 1000 \mathrm{~m}$ a.s.l. $\left(43^{\circ} 22^{\prime} 53^{\prime \prime} \mathrm{N}, 12^{\circ} 42^{\prime} 48^{\prime \prime} \mathrm{E}\right)$; exposure: W; Slope: $\approx 30 \%$. Soil: loamy-skeletal, mixed, mesic, Typic Humustepts [30]

Vegetation: Upper stratum: Pinus nigra J.F. Arnold-Lower stratus: Acer opalus subsp. obtusatum (Waldst. \& Kit. ex Willd.) Gams, Acer pseudoplatanus L., 1753, Sorbus aria (L.) Crantz, Quercus spp.-Understory: Brachypodium rupestre (Host) Roem. \& Schult, Lonicera xylosteum L., Viola alba subsp. dehnhardtii (Ten.) W. Becker, Daphne laureola L.

Fagus leafs with

twigs, and cupules

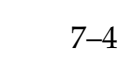

Oi $\quad 7-4$

Oe $\quad 4-1$

Oa $\quad 1-0$

A $\quad 0-8$

$\mathrm{AB} \quad 8-13$

Bw $\quad 13-26$

BC 26-47+

$\begin{array}{ccc}5 \mathrm{YR} 3 / 2 & 3 \mathrm{f} \mathrm{sbk} & \text { so, ps } \\ 5 \mathrm{YR} 3 / 3 & 3 \mathrm{f} \mathrm{sbk} & \text { so, ps } \\ 7.5 \mathrm{YR} 3 / 2 & 2 \mathrm{f} \mathrm{sbk} & \text { so, ps } \\ 7.5 \mathrm{YR} 3 / 3 & 2 \mathrm{f} \mathrm{sbk} & \text { so, ps }\end{array}$

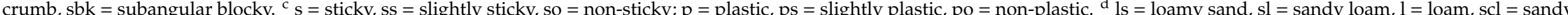
clay loam, $\mathrm{cl}=$ clay loam. ${ }^{\mathrm{e}} 0=$ absent, $1=\mathrm{few}, 2=$ plentiful $3=$ abundant; $\mathrm{mi}=$ micro, $\mathrm{vf}=$ very fine, $\mathrm{f}=$ fine, $\mathrm{m}=$ medium, $\mathrm{c}=\mathrm{coarse} .{ }^{\mathrm{f}} \mathrm{c}=$ clear; $\mathrm{w}=\mathrm{wavy}, \mathrm{s}=\mathrm{smooth} . \mathrm{g}$ on a volume basis, by sight. Fgr = fine gravelly $(2-5 \mathrm{~mm}) ; \mathrm{Mgr}=$ medium gravelly $(5-20 \mathrm{~mm}), \mathrm{Cgr}=$ coarse gravelly $(20-76 \mathrm{~mm}), \mathrm{VCgr}=$ very coarse gravelly $(>76 \mathrm{~mm})$. 


\section{References}

1. Bispo, A.; Andersen, L.; Angers, D.A.; Bernoux, M.; Brossard, M.; Cécillon, L.; Comans, R.N.J.; Harmsen, J.; Jonassen, K.; Lamé, F.; et al. Accounting for carbon stocks in soils and measuring GHGs emission fluxes from soils: Do we have the necessary standards? Front. Environ. Sci. 2017, 5. [CrossRef]

2. Dungait, J.A.J.; Hopkins, D.W.; Gregory, A.S.; Whitmore, A.P. Soil organic matter turnover is governed by accessibility not recalcitrance. Glob. Chang. Biol. 2012, 18, 1781-1796. [CrossRef]

3. Xu, M.; Li, X.; Cai, X.; Gai, J.; Li, X.; Christie, P.; Zhang, J. Soil microbial community structure and activity along a montane elevational gradient on the Tibetan Plateau. Eur. J. Soil Biol. 2014, 64, 6-14. [CrossRef]

4. Blume, E.; Bischoff, M.; Reichert, J.M.; Moorman, T.; Konopka, A.; Turco, R.F. Surface and subsurface microbial biomass, community structure and metabolic activity as a function of soil depth and season. Appl. Soil Ecol. 2002, 20, 171-181. [CrossRef]

5. Chen, L.F.; He, Z.B.; Du, J.; Yang, J.J.; Zhu, X. Patterns and environmental controls of soil organic carbon and total nitrogen in alpine ecosystems of northwestern China. Catena 2016, 137, 37-43. [CrossRef]

6. Buchan, G.D. Temperature effects in soil. In Encyclopedia of Earth Sciences Series; Springer: Berlin, Germany, 2011; Volume 4, pp. 891-895.

7. Zhang, G.N.; Chen, Z.H.; Zhang, A.M.; Chen, L.J.; Wu, Z.J. Influence of climate warming and nitrogen deposition on soil phosphorus composition and phosphorus availability in a temperate grassland, China. J. Arid Land 2014, 6, 156-163. [CrossRef]

8. Butler, S.M.; Melillo, J.M.; Johnson, J.E.; Mohan, J.; Steudler, P.A.; Lux, H.; Burrows, E.; Smith, R.M.; Vario, C.L.; Scott, L.; et al. Soil warming alters nitrogen cycling in a New England forest: Implications for ecosystem function and structure. Oecologia 2012, 168, 819-828. [CrossRef]

9. Vincent, A.G.; Sundqvist, M.K.; Wardle, D.A.; Giesler, R. Bioavailable soil phosphorus decreases with increasing elevation in a subarctic tundra landscape. PLoS ONE 2014, 9, e92942. [CrossRef]

10. Schindlbacher, A.; De Gonzalo, C.; Díaz-Pinés, E.; Gíorra, P.; Matthews, B.; Inclán, R.; Zechmeister-Boltenstern, S.; Rubio, A.; Jandl, R. Temperature sensitivity of forest soil organic matter decomposition along two elevation gradients. J. Geophys. Res. Biogeosci. 2010, 115. [CrossRef]

11. Cardelli, V.; De Feudis, M.; Fornasier, F.; Massaccesi, L.; Cocco, S.; Agnelli, A.; Weindorf, D.C.; Corti, G. Changes of topsoil under Fagus sylvatica along a small latitudinal-altitudinal gradient. Geoderma 2019, 344, 164-178. [CrossRef]

12. Kobler, J.; Zehetgruber, B.; Dirnböck, T.; Jandl, R.; Mirtl, M.; Schindlbacher, A. Effects of aspect and altitude on carbon cycling processes in a temperate mountain forest catchment. Landsc. Ecol. 2019, 34, 325-340. [CrossRef]

13. Gutiérrez-Girón, A.; Díaz-Pinés, E.; Rubio, A.; Gavilán, R.G. Both altitude and vegetation affect temperature sensitivity of soil organic matter decomposition in Mediterranean high mountain soils. Geoderma 2015, 237-238, 1-8. [CrossRef]

14. Chang, R.; Wang, G.; Fei, R.; Yang, Y.; Luo, J.; Fan, J. Altitudinal Change in Distribution of Soil Carbon and Nitrogen in Tibetan Montane Forests. Soil Sci. Soc. Am. J. 2015, 79, 1455-1469. [CrossRef]

15. Tsozué, D.; Nghonda, J.P.; Tematio, P.; Basga, S.D. Changes in soil properties and soil organic carbon stocks along an elevation gradient at Mount Bambouto, Central Africa. Catena 2019, 175, 251-262. [CrossRef]

16. De Feudis, M.; Cardelli, V.; Massaccesi, L.; Trumbore, S.E.; Vittori Antisari, L.; Cocco, S.; Corti, G.; Agnelli, A. Small altitudinal change and rhizosphere affect the SOM light fractions but not the heavy fraction in European beech forest soil. Catena 2019, 181, 104091. [CrossRef]

17. De Feudis, M.; Cardelli, V.; Massaccesi, L.; Lagomarsino, A.; Fornasier, F.; Westphalen, D.J.; Cocco, S.; Corti, G.; Agnelli, A. Influence of altitude on biochemical properties of European Beech (Fagus sylvatica L.) forest soils. Forests 2017, 8, 213. [CrossRef]

18. De Feudis, M.; Cardelli, V.; Massaccesi, L.; Hofmann, D.; Berns, A.E.; Bol, R.; Cocco, S.; Corti, G.; Agnelli, A. Altitude affects the quality of the water-extractable organic matter (WEOM) from rhizosphere and bulk soil in European beech forests. Geoderma 2017, 302, 6-13. [CrossRef]

19. Von Lützow, M.; Kögel-Knabner, I. Temperature sensitivity of soil organic matter decomposition-what do we know? Biol. Fertil. Soils 2009, 46, 1-15. [CrossRef]

20. Paul, E.A. The nature and dynamics of soil organic matter: Plant inputs, microbial transformations, and organic matter stabilization. Soil Biol. Biochem. 2016, 98, 109-126. [CrossRef] 
21. Quideau, S.A.; Chadwick, O.A.; Benesi, A.; Graham, R.C.; Anderson, M.A. A direct link between forest vegetation type and soil organic matter composition. Geoderma 2001, 104, 41-60. [CrossRef]

22. Ayres, E.; Steltzer, H.; Berg, S.; Wallenstein, M.D.; Simmons, B.L.; Wall, D.H. Tree species traits influence soil physical, chemical, and biological properties in high elevation forests. PLoS ONE 2009, 4. [CrossRef] [PubMed]

23. Smolander, A.; Loponen, J.; Suominen, K.; Kitunen, V. Organic matter characteristics and C and N transformations in the humus layer under two tree species, Betula pendula and Picea abies. Soil Biol. Biochem. 2005, 37, 1309-1318. [CrossRef]

24. Aponte, C.; García, L.V.; Marañón, T. Tree species effect on litter decomposition and nutrient release in Mediterranean oak Fforests changes over time. Ecosystems 2012, 15, 1204-1218. [CrossRef]

25. Berger, T.W.; Duboc, O.; Djukic, I.; Tatzber, M.; Gerzabek, M.H.; Zehetner, F. Decomposition of beech (Fagus sylvatica) and pine (Pinus nigra) litter along an Alpine elevation gradient: Decay and nutrient release. Geoderma 2015, 251-252, 92-104. [CrossRef]

26. Badalamenti, E.; Battipaglia, G.; Gristina, L.; Novara, A.; Ruhl, J.; Sala, G.; Sapienza, L.; Valentini, R.; La Mantia, T. Carbon stock increases up to old growth forest along a secondary succession in Mediterranean island ecosystems. PLOS ONE 2019, 14. [CrossRef]

27. Wan, Q.; Zhu, G.; Guo, H.; Zhang, Y.; Pan, H.; Yong, L.; Ma, H. Influence of Vegetation Coverage and Climate Environment on Soil Organic Carbon in the Qilian Mountains. Sci. Rep. 2019, 9, 17623. [CrossRef]

28. Regione Umbria. Parco del Monte Cucco-Aspetti Vegetazionali, Botanici e Forestali. Piani dei Parchi Regionali dell'Umbria. Available online: http://www.regione.umbria.it/documents/18/2512711/Cucco_ vegetazione_ott_15.pdf/0fd79a30-6fea-4acd-9dac-5917c2a86a20 (accessed on 15 June 2020).

29. Schoeneberger, P.J.; Wysocki, D.A.; Benham, E.C. Soil Survey Staff Field Book for Describing and Sampling Soils; Version 3.0; Natural Resources Conservation Service, National Soil Survey Center: Lincoln, NE, USA, 2012.

30. Soil Survey Staff. Keys to Soil Taxonomy, 12th ed.; USDA-Natural Resources Conservation Service: Washington, DC, USA, 2014.

31. Sparks, D.L.; Page, A.L.; Helmke, P.A.; Loeppert, R.H.; Nelson, D.W.; Sommers, L.E. Total Carbon, Organic Carbon, and Organic Matter. In Methods of Soil Analysis; American Society of Agronomy, Inc.: Madison, WI, USA; Soil Science Society of America, Inc.: Madison, WI, USA, 1996.

32. Swift, R.S. Organic Matter Characterization. In Methods of Soil Analysis; American Society of Agronomy, Inc.: Madison, WI, USA; Soil Science Society of America, Inc.: Madison, WI, USA, 2018; pp. 1011-1069.

33. Vance, E.D.; Brookes, P.C.; Jenkinson, D.S. An extraction method for measuring soil microbial biomass C. Soil Biol. Biochem. 1987, 19, 703-707. [CrossRef]

34. R Core Team. R: A Language and Environment for Statistical Computing; R Foundation for Statistical Computing: Vienna, Austria, 2018.

35. Bonarelli, G.; Principi, P.; Pilotti, C.; Scarsella, F.; Lipparini, T.; Moretti, A.; Selli, R. Carta Geologica d'Italia Alla Scala 1:100,000; Foglio 116; Servizio Geologico D’Italia: Gubbio, Italy, 1952.

36. Jobbágy, E.; Jackson, R. The vertical distribution of soil organic carbon and its relation to climate and vegetation. Ecol. Appl. 2000, 10, 423-436. [CrossRef]

37. Massaccesi, L.; Bardgett, R.D.; Agnelli, A.; Ostle, N.; Wilby, A.; Orwin, K.H. Impact of plant species evenness, dominant species identity and spatial arrangement on the structure and functioning of soil microbial communities in a model grassland. Oecologia 2015, 177, 747-759. [CrossRef]

38. Bardgett, R.D.; Mommer, L.; De Vries, F.T. Going underground: Root traits as drivers of ecosystem processes. Trends Ecol. Evol. 2014, 29, 692-699. [CrossRef]

39. Newcomb, C.J.; Qafoku, N.P.; Grate, J.W.; Bailey, V.L.; De Yoreo, J.J. Developing a molecular picture of soil organic matter-mineral interactions by quantifying organo-mineral binding. Nat. Commun. 2017, 8.

40. Fissore, C.; Giardina, C.P.; Kolka, R.K.; Trettin, C.C.; King, G.M.; Jurgensen, M.F.; Barton, C.D.; Mcdowell, S.D. Temperature and vegetation effects on soil organic carbon quality along a forested mean annual temperature gradient in North America. Glob. Chang. Biol. 2008, 14, 193-205. [CrossRef]

41. Eusterhues, K.; Rumpel, C.; Kleber, M.; Kögel-Knabner, I. Stabilisation of soil organic matter by interactions with minerals as revealed by mineral dissolution and oxidative degradation. Org. Geochem. 2003, 34, 1591-1600. [CrossRef]

42. Zianis, D.; Mencuccini, M. Aboveground net primary productivity of a beech (Fagus moesiaca) forest: A case study of Naousa forest, northern Greece. Tree Physiol. 2005, 25, 713-722. [CrossRef] [PubMed] 
43. Gebauer, R.; Volařík, D.; Funda, T.; Fundová, I.; Kohutka, A.; Klapetek, V.; Martinková, M.; Anenkhonov, O.A.; Razuvaev, A. Pinus pumila growth at different altitudes in the Svyatoi Nos Peninsula (Russia). J. For. Sci. 2010, 56, 101-111. [CrossRef]

44. Liu, X.Z.; Gao, C.C.; Su, Q.; Zhang, Y.; Song, Y. Altitudinal trends in $813 \mathrm{C}$ value, stomatal density and nitrogen content of Pinus tabuliformis needles on the southern slope of the middle Qinling Mountains, China. J. Mt. Sci. 2016, 13, 1066-1077. [CrossRef]

45. Kalbitz, K.; Kaiser, K. Contribution of dissolved organic matter to carbon storage in forest mineral soils. J. Plant. Nutr. Soil Sci. 2008, 171, 52-60. [CrossRef]

46. Zhu, J.; Yang, W.; He, X. Temporal dynamics of abiotic and biotic factors on leaf litter of three plant species in relation to decomposition rate along a subalpine elevation gradient. PLoS ONE 2013, 8. [CrossRef]

47. Xu, G.; Chen, J.; Berninger, F.; Pumpanen, J.; Bai, J.; Yu, L.; Duan, B. Labile, recalcitrant, microbial carbon and nitrogen and the microbial community composition at two Abies faxoniana forest elevations under elevated temperatures. Soil Biol. Biochem. 2015, 91,1-13. [CrossRef]

48. Fernández Sanjurjo, M.J.; Corti, G.; Certini, G.; Ugolini, F.C. Pedogenesis induced by Genista aetnensis (Biv.) DC. on basaltic pyroclastic deposits at different altitudes, Mt. Etna, Italy. Geoderma 2003, 115, 223-243. [CrossRef]

49. Paolo Di Lonardo, D.; De Boer, W.; Zweers, H.; van der Wal, A. Effect of the amount of organic trigger compounds, nitrogen and soil microbial biomass on the magnitude of priming of soil organic matter. PLoS ONE 2019, 14, e0216730. [CrossRef] [PubMed]

50. Thakur, M.P.; Milcu, A.; Manning, P.; Niklaus, P.A.; Roscher, C.; Power, S.; Reich, P.B.; Scheu, S.; Tilman, D.; Ai, F.; et al. Plant diversity drives soil microbial biomass carbon in grasslands irrespective of global environmental change factors. Glob. Chang. Biol. 2015, 21, 4076-4085. [CrossRef] [PubMed]

51. Fanin, N.; Hättenschwiler, S.; Fromin, N. Litter fingerprint on microbial biomass, activity, and community structure in the underlying soil. Plant. Soil 2014, 379, 79-91. [CrossRef]

52. Li, W.; Yang, G.; Chen, H.; Tian, J.; Zhang, Y.; Zhu, Q.; Peng, C.; Yang, J. Soil available nitrogen, dissolved organic carbon and microbial biomass content along altitudinal gradient of the eastern slope of Gongga Mountain. Acta Ecol. Sin. 2013, 33, 266-271. [CrossRef]

53. Djukic, I.; Zehetner, F.; Mentler, A.; Gerzabek, M.H. Microbial community composition and activity in different Alpine vegetation zones. Soil Biol. Biochem. 2010, 42, 155-161. [CrossRef]

54. Kaiser, K.; Kalbitz, K. Cycling downwards-Dissolved organic matter in soils. Soil Biol. Biochem. 2012, 52, 29-32. [CrossRef]

55. Smolander, A.; Kitunen, V. Soil microbial activities and characteristics of dissolved organic C and $\mathrm{N}$ in relation to tree species. Soil Biol. Biochem. 2002, 34, 651-660. [CrossRef]

56. Malik, A.A.; Puissant, J.; Buckeridge, K.M.; Goodall, T.; Jehmlich, N.; Chowdhury, S.; Gweon, H.S.; Peyton, J.M.; Mason, K.E.; van Agtmaal, M.; et al. Land use driven change in soil pH affects microbial carbon cycling processes. Nat. Commun. 2018, 9, 3591. [CrossRef]

57. Motavalli, P.P.; Palm, C.A.; Parton, W.J.; Elliott, E.T.; Frey, S.D. Soil pH and organic C dynamics in tropical forest soils: Evidence from laboratory and simulation studies. Soil Biol. Biochem. 1995, 27, 1589-1599. [CrossRef]

58. Cerri, C.C.; Jenkinson, D.S. Formation of Microbial Biomass During the Decomposition of 14C Labelled Ryegrass in Soil. J. Soil Sci. 1981, 32, 619-626. [CrossRef]

59. Curtin, D.; Peterson, M.E.; Anderson, C.R. pH-dependence of organic matter solubility: Base type effects on dissolved organic C, N, P, and S in soils with contrasting mineralogy. Geoderma 2016, 271, 161-172. [CrossRef]

60. Agnelli, A.; Massaccesi, L.; De Feudis, M.; Cocco, S.; Courchesne, F.; Corti, G. Holm oak (Quercus ilex L.) rhizosphere affects limestone-derived soil under a multi-centennial forest. Plant. Soil 2016, 400, 297-314. [CrossRef]

61. Bölscher, T.; Wadsö, L.; Börjesson, G.; Herrmann, A.M. Differences in substrate use efficiency: Impacts of microbial community composition, land use management, and substrate complexity. Biol. Fertil. Soils 2016, 52, 547-559. [CrossRef]

(C) 2020 by the authors. Licensee MDPI, Basel, Switzerland. This article is an open access article distributed under the terms and conditions of the Creative Commons Attribution (CC BY) license (http://creativecommons.org/licenses/by/4.0/). 